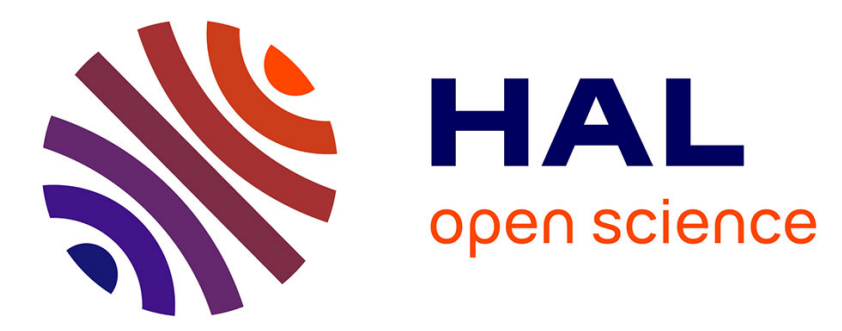

\title{
Rift-to-collision transition recorded by tectono-thermal evolution of the northern Pyrenees
}

\author{
Arnaud Vacherat, Frédéric Mouthereau, Raphaël Pik, Nicolas Bellahsen, \\ Cécile Gautheron, Matthias Bernet, Maxime Daudet, Jocelyn Balansa, \\ Bouchaib Tibari, Rosella Pinna Jamme, et al.
}

\section{To cite this version:}

Arnaud Vacherat, Frédéric Mouthereau, Raphaël Pik, Nicolas Bellahsen, Cécile Gautheron, et al.. Rift-to-collision transition recorded by tectono-thermal evolution of the northern Pyrenees. Tectonics, 2016, 35, pp.907-933. 10.1002/2015TC004016 . hal-01304170

\section{HAL Id: hal-01304170 https://hal.sorbonne-universite.fr/hal-01304170}

Submitted on 19 Apr 2016

HAL is a multi-disciplinary open access archive for the deposit and dissemination of scientific research documents, whether they are published or not. The documents may come from teaching and research institutions in France or abroad, or from public or private research centers.
L'archive ouverte pluridisciplinaire HAL, est destinée au dépôt et à la diffusion de documents scientifiques de niveau recherche, publiés ou non, émanant des établissements d'enseignement et de recherche français ou étrangers, des laboratoires publics ou privés. 


\section{Tectonics}

\section{RESEARCH ARTICLE}

10.1002/2015TC004016

Key Points:

- A tectonothermal model of rift-to-collision transition is presented for the Pyrenees

- Thinning events in Late Paleozoic and mid-Cretaceous led to focus deformation in northern Pyrenees - Cooling and exhumation occurs at 50-35 Ma when less thinned and stronger proximal margins collided

Supporting Information:

- Supporting Information S1

- Table S2

- Table S3

- Figure S1a

- Figure S1b

- Figure S1c

Correspondence to:

A. Vacherat,

arnaud.vacherat@gmail.com

\section{Citation:}

Vacherat, A., et al. (2016), Rift-to-collision transition recorded by tectonothermal evolution of the northern Pyrenees, Tectonics, 35, doi:10.1002/2015TC004016.

Received 24 AUG 2015 Accepted 15 MAR 2016 Accepted article online 24 MAR 2016

(2016. American Geophysical Union. All Rights Reserved.

\section{Rift-to-collision transition recorded by tectonothermal evolution of the northern Pyrenees}

\author{
Arnaud Vacherat ${ }^{1,2,3}$, Frédéric Mouthereau ${ }^{3}$, Raphaël Pik ${ }^{2}$, Nicolas Bellahsen ${ }^{1}$, Cécile Gautheron ${ }^{4}$, \\ Matthias Bernet ${ }^{5}$, Maxime Daudet ${ }^{3}$, Jocelyn Balansa ${ }^{3}$, Bouchaib Tibari ${ }^{2}$, Rosella Pinna Jamme ${ }^{4}$, \\ and Julien Radal ${ }^{1}$
}

${ }^{1}$ Institut des Sciences de la Terre de Paris, Sorbonne Universités, UPMC Univ Paris 06, CNRS, Paris, France, ${ }^{2}$ CRPG, UMR 7358 CNRS-Université de Lorraine, Vandoeuvre-lès-Nancy, France, ${ }^{3}$ Geoscience Environnement Toulouse (GET), Université de Toulouse, UPS, Université Paul Sabatier, CNRS, IRD, Toulouse, France, ${ }^{4}$ GEOPS, Univ Paris Sud, CNRS, Université Paris-Saclay, Orsay, France, ${ }^{5}$ Institut des Sciences de la Terre (ISTerre), Université Grenoble-Alpes, Grenoble, France

Abstract The impact of rift-related processes on tectonic and thermal evolution of collisional orogens is poorly documented. Here, we study the northern Pyrenees, a region that has preserved a geological record of the transition from rifting to collision. Using modeling of new low-temperature thermochronological data, including fission track and (U-Th)/He on apatite and zircon, we propose a temporal reconstruction of the inversion of the European rifted margin. Our data confirm that rifting and related cooling started in the Late Paleozoic-Triassic. Throughout the Jurassic and Early Cretaceous the European margin recorded slow heating during postrift subdsidence. Modeling of thermochronological data allows distinguishing subsidence and denudation controlled by south dipping normal faults in granitic massifs that reflect a second episode of crustal thinning at 130-110 Ma. Following onset of convergence at $83 \mathrm{Ma}$, shortening accumulated into the weak and hot Albian-Cenomanian rift basins floored by both hyperextended continental crust and exhumed subcontinental mantle. The lack of cooling during this initial stage of convergence is explained by the persistence of a high geothermal gradient. The onset of exhumation-related cooling is recognized in the whole Pyrenean region at 50-35 Ma. This timing reveals that the main phase of mountain building started when hyperextended rift basins closed and collision between proximal domains of the rifted margin occurred.

\section{Introduction}

The thermotectonic properties and the architecture of rifted margins are shown to have a significant impact on the temporal and spatial distribution of shortening and thermal evolution of orogenic belts [Mohn et al., 2011, 2014; Jammes and Huismans, 2012; Masini et al., 2012; McIntosh et al., 2013; Beltrando et al., 2014; Mouthereau et al., 2013, 2014; Bellahsen et al., 2014; Mesalles et al., 2014; Vacherat et al., 2014]. The main observations supporting the major control by tectonothermal inheritance on collision evolution is established in fold-and-thrust belts that deform proximal margins [Mouthereau et al., 2013]. But the effects of inherited, rift-related, physical parameters and structures are expected to be more significant at collision initiation, when the distal margin is accreted. In addition, inherited crustal inhomogeneities related to the proximal/distal transition across rifted margins is suggested to dictate the evolution from submarine continental accretion to subaerial collisional stages in Taiwan [Mesalles et al., 2014], the Alps [Mohn et al., 2014] and the Pyrenees [Mouthereau et al., 2014; Vacherat et al., 2014; Tugend et al., 2014, 2015]. The tectonic processes at play in the crust and lithosphere and the thermal evolution during the rift-to-collision transition are, however, still poorly documented.

Here we examine the thermal and exhumational evolution of the northern Pyrenees formed by the accretion of the European crust. This region is understood to reflect deformation of the variscan crystalline basement and its Mesozoic sedimentary cover that were originally positioned at the transition between the proximal and distal European rifted margins [e.g., Mouthereau et al., 2014].

The Pyrenees are a typical asymmetric doubly verging collision wedge that results from collision between the Iberian and European plates since the Late Cretaceous [Choukroune, 1989; Muñoz, 1992; Beaumont et al., 2000]. The central part of the mountain belt comprises the Axial Zone in which stacked crustal units exhume the Paleozoic crystalline basement (Figures 1 and 2). It is flanked by two opposite vergent fold-and-thrust belts, the South and North Pyrenean Zones (SPZ and NPZ), and two foreland basins, the Ebro and the Aquitaine basins. 


\section{QAGU Tectonics}

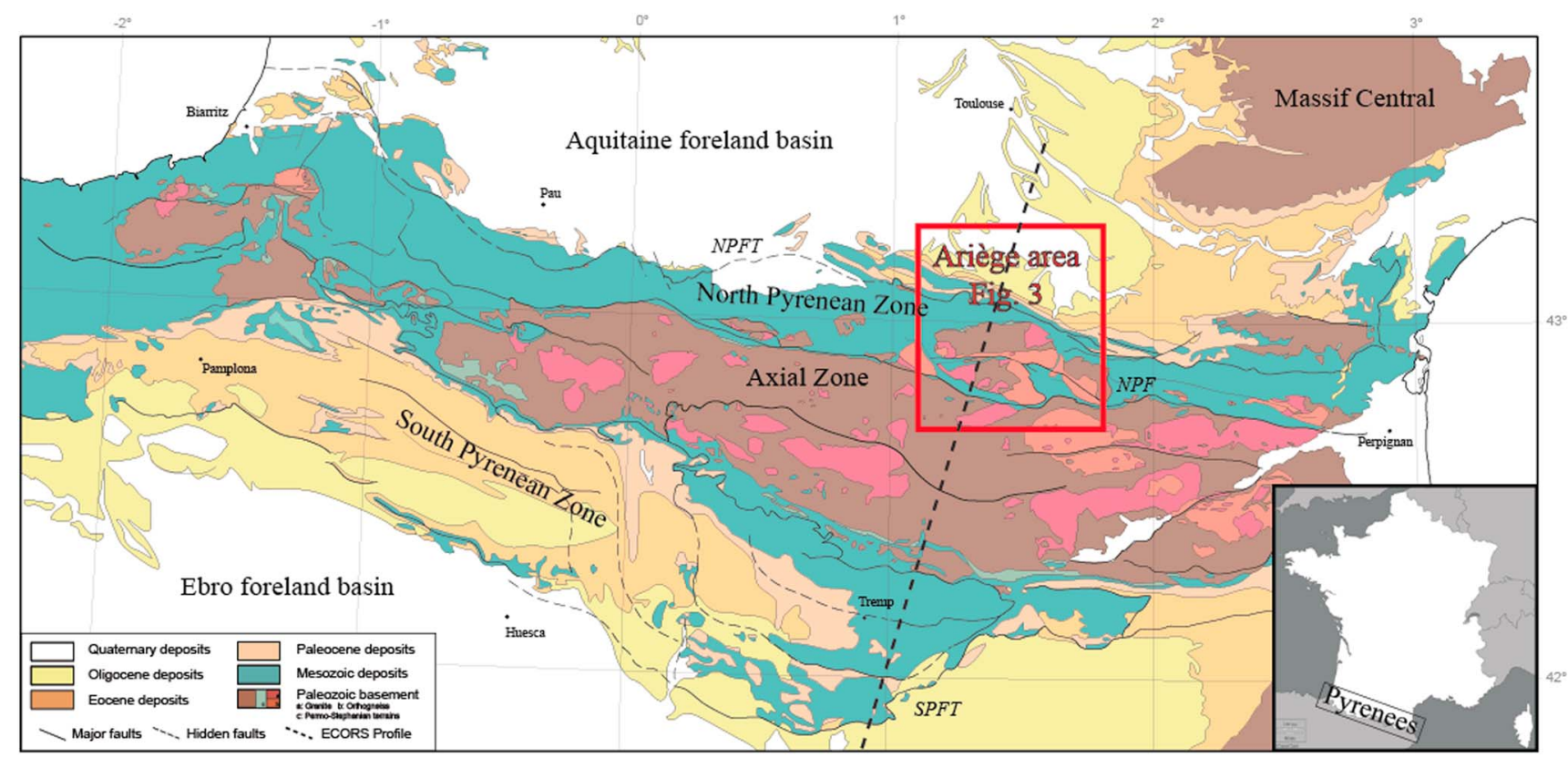

Figure 1. Geological map of the Pyrenees and location of the study area (Figure 3).

Prior to collision, a rifting phase led to exhumation of the subcontinental lithospheric mantle during the Albian, which is currently exposed in the NPZ as Iherzolitic massifs [Vielzeuf and Kornprobst, 1984; Fortané et al., 1986; Lagabrielle and Bodinier, 2008; Jammes et al., 2009; Lagabrielle et al., 2010; Clerc et al., 2012]. Hyperextension of continental lithosphere recorded by mantle exhumation caused a high-temperature,

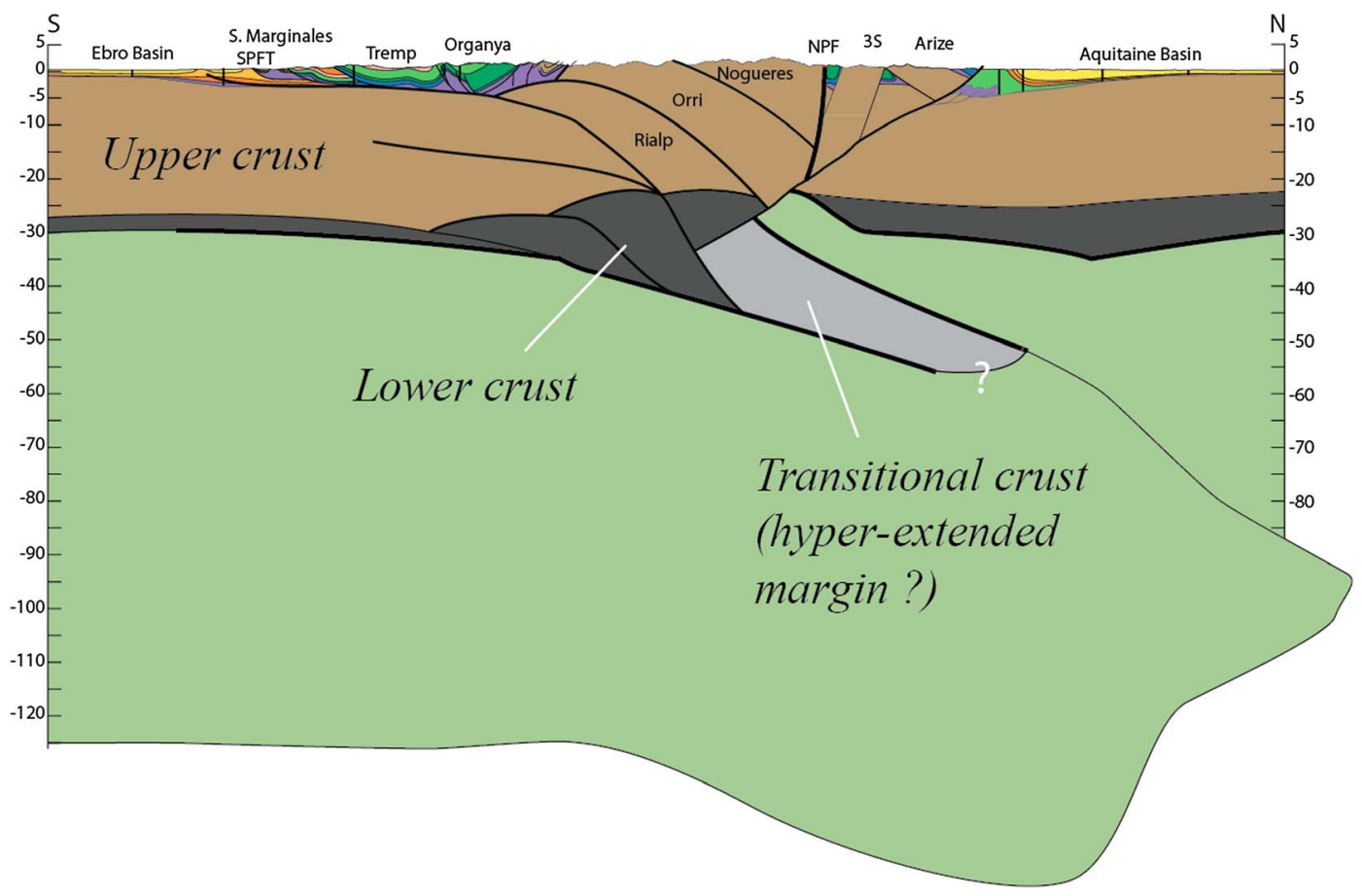

Figure 2. Lithosphere-scale section across the Pyrenees (see location in Figure 1). This interpretation accounts for a recent cross section proposed by Mouthereau et al. [2014] that was updated considering the migration of teleseismic $P$ wave data from Chevrot et al. [2015]. This version is aimed at accounting for the subduction of the distal, hyperextended margin at depth. Note that the thickening of the lower crust relfects the thickening of the lberia proximal margin and forms the main part of the mountain root. 
low-pressure metamorphic event [Montigny et al., 1986; Golberg and Leyreloup, 1990; Clerc and Lagabrielle, 2014; Clerc et al., 2015; Corre et al., 2016] and was associated with the circulation of hot fluids [Dauteuil and Ricou, 1989; Boulvais et al., 2006, 2007; Poujol et al., 2010; Fallourd et al., 2014] and alkaline magmatism [Montigny et al., 1986].

In the western Pyrenees, a recent thermochronological study of Albian sediments elucidates the long-term time-temperature evolution from rifting to collision [Vacherat et al., 2014]. The time-temperature history modeling hints at a remarkable heating episode at circa $110 \mathrm{Ma}$ recorded by geothermal gradients as high as $80^{\circ} \mathrm{C} / \mathrm{km}$ that resulted from rift-related mantle exhumation and sediment burial. That study also emphasizes a noticeable cooling event at $50 \mathrm{Ma}$ consistent with time-temperature paths modeled for the central Pyrenees, indicating a regional event [e.g., Fitzgerald et al., 1999; Sinclair et al., 2005].

Most of the studies dealing with the thermal history of the central Pyrenees, including the NPZ, have focused on the latest stage of orogenic growth, using apatite fission track and (U-Th)/He on apatite analyses [Yelland, 1991; Morris et al., 1998; Fitzgerald et al., 1999; Sinclair et al., 2005; Maurel et al., 2007; Gibson et al., 2007]. Data on the northern side of the belt, of interest in this study, are too scarce to allow understanding of the role of rift-related processes in the evolution of the entire orogenic prism. To evaluate this further in the northern central Pyrenees, new thermochronological data and modeling of the time-temperature paths are needed. With this aim, we focus on the Ariège region (Figure 3 ) and provide new apatite and zircon fission track (AFT and ZFT) and (U-Th-Sm)/He (AHe and ZHe) data on the Arize and Trois-Seigneurs (3S) Paleozoic crystalline Massifs. We also performed detrital ZHe and ZFT analyses on the Camarade basin, an inverted Albian "black flyschs" basin located on the hangingwall of the frontal thrust. The time-temperature history is then obtained by inverse modeling of our data, using an approach that accounts for diffusion and annealing kinetics of a large range of thermochronological systems.

\section{Geological Setting and Open Questions}

\subsection{The Northern Pyrenees and Overview of Low-Temperature Thermochronological Constraints in} the Pyrenees

The NPZ distinctively consists of thick and variably metamorphosed Mesozoic sedimentary rocks that developed in basins during the Albian extension period (Figures 3 and 4). The basins and their Paleozoic crystalline basement are positioned in the hangingwall of the North Pyrenean Frontal Thrust (NPFT) and are thrusted over the sub-Pyrenean domain defined by folded and faulted cenozoic sediments of the Aquitanian foreland basin. Between the NPZ and the Axial Zone, the North Pyrenean Fault (NPF) represents a narrow domain of Mesozoic marine sediments that recorded high-temperature metamorphism (up to $600^{\circ} \mathrm{C}$ ) [Montigny et al., 1986; Golberg and Leyreloup, 1990; Clerc and Lagabrielle, 2014] and ductile deformation. Alkaline magmatism, hydrothermal fluid circulation associated with hot $\mathrm{Na}$, and $\mathrm{Na}-\mathrm{Ca}\left(550^{\circ} \mathrm{C}\right)$ mineralizations are also found along the NPF [Boulvais et al., 2006; Poujol et al., 2010; Fallourd et al., 2014]. Age constraints on the high-temperature event indicate a heating episode between $110 \mathrm{Ma}$ and $85 \mathrm{Ma}$, synchronous with Albian extension and exhumation of subcontinental lithospheric mantle [Montigny et al., 1986; Clerc et al., 2012, 2015; Vauchez et al., 2013; Clerc and Lagabrielle, 2014; Masini et al., 2014; Vacherat et al., 2014; Tugend et al., 2014, 2015; Chelalou et al., 2016]. Thermal models further suggest that crustal breakup led to the exhumation of the subcontinental mantle at the base of the Albo-Cenomanian sedimentary basins, characterized by high thermal gradients [e.g., Vacherat et al., 2014]. All these constraints support that hyperextension occurred in a region close to the NPF.

Despite the recent efforts to constrain the amount and timing of shortening in the Pyrenees (see Mouthereau et al. [2014] for a synthesis), the role of the NPF is still questioned. Kinematic models interpret this fault as an ancient transform plate boundary fault accommodating sinistral strike-slip fault and oblique extension during the main rifting phase in the Aptian-Albian [Le Pichon et al., 1970; Olivet, 1996; Lagabrielle and Bodinier, 2008] or as an extensional fault accommodating mainly arc-normal extension [Jammes et al., 2009; Lagabrielle et al., 2010; Masini et al., 2014; Clerc and Lagabrielle, 2014; Mouthereau et al., 2014]. Alternatively, the NPF is understood to have accommodated little strike-slip movement but was a site of diffuse transtension between propagating rift systems since the Late Jurassic [e.g., Tugend et al., 2015].

Restoring the suture domain is key for plate reconstructions. However, the original width of the suture domain cannot be directly deduced from classical balancing techniques as most of the Mesozoic terrains located in the 


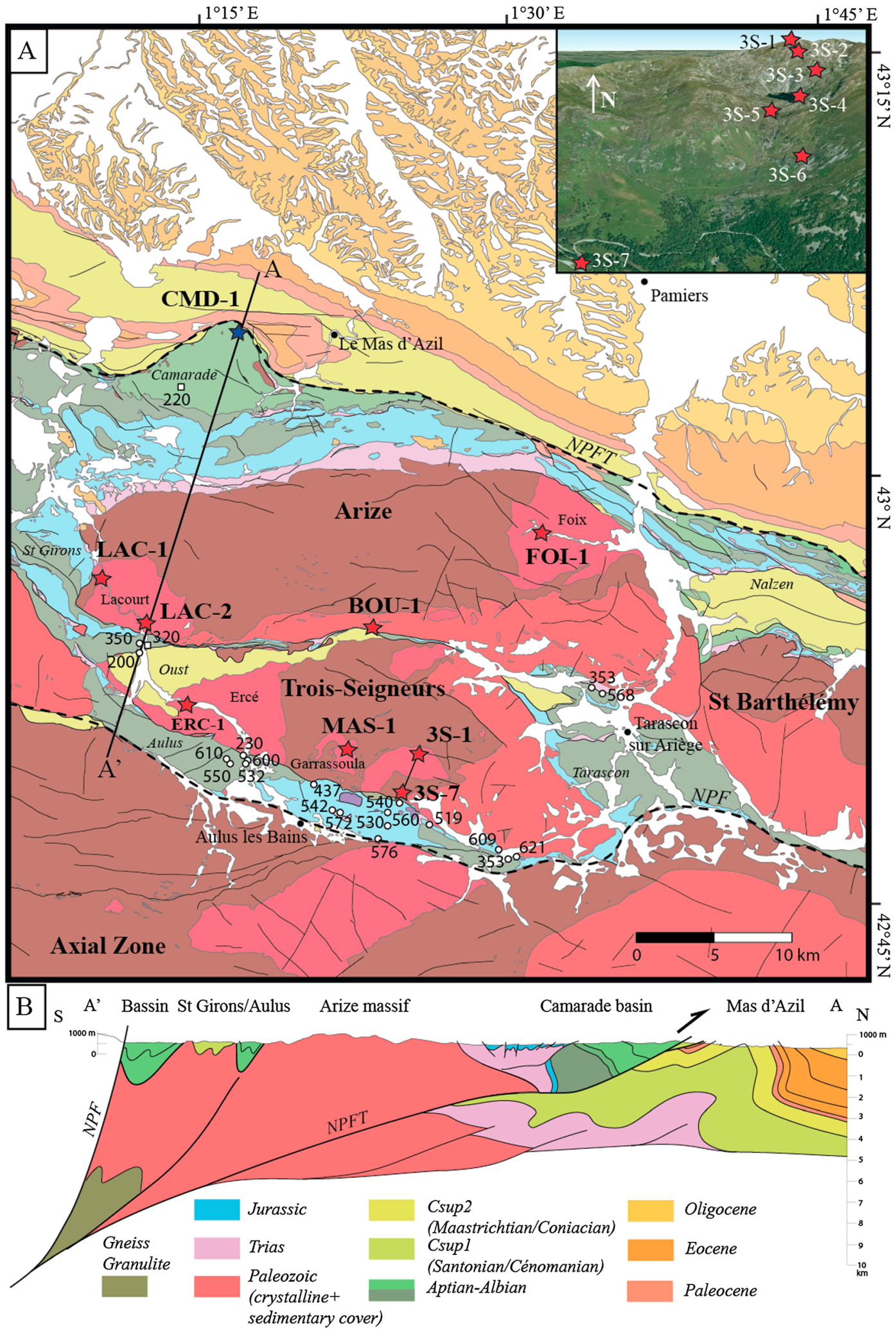

Figure 3. (a) Geological map of the study area. Red and blue stars depict the position of studied granite and detrital samples, respectively. White circles and squares correspond to samples from which RSCM temperatures were obtained from Clerc and Lagabrielle [2014], including two new estimates (Table S1). The inset in the upper right corner shows a 3-D view of the $3 \mathrm{~S}$ massif and the position of samples collected for the $3 \mathrm{~S}$ age elevation profile. (b) Cross section of the western Ariège area, west of $1^{\circ} 30^{\prime} \mathrm{E}$ (see location in Figure 3a). 


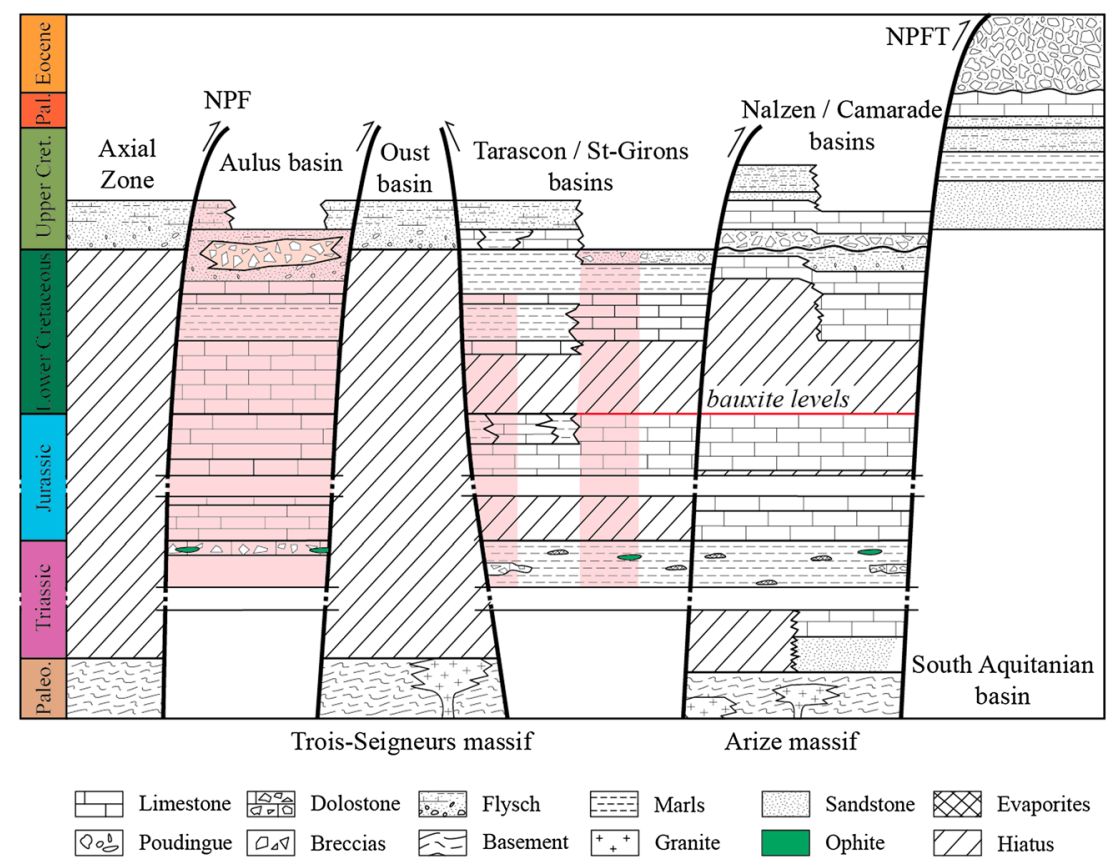

Figure 4. Synthetic lithostratigraphy and stratigraphic and structural organization of Meso-Cenozoic successions in basins and Paleozoic massifs in the Ariège area. The high-temperature, low-pressure metamorphism event that affected the Aulus basin and the southern parts of the Saint-Girons and Tarascon basins is represented here in light red.

vicinity of the NPF are now missing due to underthrusting or subaerial erosion. A low shortening estimate of $\sim 30 \mathrm{~km}$ is proposed by balancing the northern part of the Etude Continentale et Océanique par Reflexion et Refraction Sismique (ECORS) profile [Baby et al., 1988; Déramond et al., 1990], but an additional amount of $\sim 50 \mathrm{~km}$ accommodated in the suture domain has to be accounted for [Mouthereau et al., 2014].

Based on the comparison between the Iberian and European plate convergence history, the timing of the first contact between the opposite proximal margins allows resolving the width of the subducted hyperextended crust to $50 \mathrm{~km}$ [Mouthereau et al., 2014]. This is in good agreement with the deep structure of the Pyrenean orogen imaged by new teleseismic migrations data [Chevrot et al., 2015]. To account for these new data, we present in Figure 2 a revision of our published cross section [Mouthereau et al., 2014], which accounts for a lower slab dip of Iberia, the absence of high $P$ wave anomalies below the NPZ, and the progressive disappearance of the Iberia Moho. The attenuated Moho reflection is interpreted to reflect the serpentinization of the mantle inherited from hyperextension at the distal margin [Chevrot et al., 2015]. In this interpretation, the middle-lower crust of the Iberia proximal margin is tectonically thickened and forms the deep part of the mountain root.

The main collision-related unroofing stage, as inferred from bedrock AFT and AHe data, started at circa $50 \mathrm{Ma}$ [Yelland, 1991; Morris et al., 1998; Fitzgerald et al., 1999; Sinclair et al., 2005; Maurel et al., 2007; Gibson et al., 2007; Bosch et al., 2016]. This event was associated with a southward younging trend of thermochronological ages and the growth of significant topography [Brunet, 1986; Fitzgerald et al., 1999; Sinclair et al., 2005; Huyghe et al., 2009; Whitchurch et al., 2011; Mouthereau et al., 2014].

According to existing plate reconstructions, the onset of convergence between Iberia and Europe began 83 Ma ago [Roest and Srivastava, 1991; Olivet, 1996; Rosenbaum et al., 2002]. There is, however, only scarce evidence supporting a coeval cooling event, which is only inferred from detrital ZHe, ZFT, and AFT grain age populations recovered from sediments of the southern foreland [Whitchurch et al., 2011; Filleaudeau et al., 2011; Beamud et al., 2011]. The difficulty of resolving this cooling period from the detrital thermochronology analysis may reflect the time needed to erode the nonreset and partially reset portions of the crust [Mouthereau et al., 2014]. Using modeling of higher temperature thermochronological data in the Axial Zone, Metcalf et al. [2009] reconstructed a heating period starting at $\sim 65 \mathrm{Ma}$ followed by rapid cooling since $50 \mathrm{Ma}$, in relation to tectonic burial and onset of nappe stacking in the orogenic prism. 
The lack of a cooling event at the onset of convergence can also be explained by the time needed to relax the thermal crustal anomaly as shortening successively involves a hot and extremely thinned crust, then a cooler and thicker crustal portion [Mouthereau et al., 2014; Vacherat et al., 2014]. This period of thermal transition is suggested to be shorter in the Central Pyrenees [Mouthereau et al., 2014] than to the west [Vacherat et al., 2014], because of the laterally variable sizes of the hot hyperextended domains. By inverse modeling of detrital AFT data from the northern foreland sediments, Mouthereau et al. [2014] detected a period of slow cooling from $105 \mathrm{Ma}$, followed by faster cooling after $75-70 \mathrm{Ma}\left(5.5^{\circ} \mathrm{C} / \mathrm{Myr}\right)$. To better resolve the time-temperature evolution of the NPZ from extension to collision, we focused on the Ariège area (Central NPZ, Figure 3), a key area of the northern Pyrenees positioned along the ECORS profile.

\subsection{Geology, Structure, and Thermochronological Constraints in the Ariège Region} 2.2.1. Stratigraphy and Structural Units in the NPZ

The NPZ of the Ariège region (Figure 3a) consists of a Paleozoic crystalline basement (Arize and Trois-Seigneurs Massifs) that lies in tectonic or stratigraphic contact with Early-Late Cretaceous basins (Aulus, Tarascon, Saint-Girons, Oust-Massat, Nalzen, and Camarade basins). Sediments of these basins were heated during rifting and show high-temperature (HT) metamorphism and ductile structural fabrics (e.g., cleavages, folding, and stretching lineations) close to the NPF [Choukroune, 1974; Montigny et al., 1986; Golberg and Leyreloup, 1990; Clerc and Lagabrielle, 2014; Mouthereau et al., 2014] (Figures 3b and 4).

The Aulus basin, positioned close to the NPF, is in tectonic contact to the north with the Trois-Seigneurs Massif. This contact is outlined by deformed Triassic to Jurassic successions and granulite lenses. The sedimentary succession (5-5.5 km) spans the Late Triassic to the Late Cretaceous. It includes post-HT metamorphism polymictic breccias of possible Cenomanian age containing locally abundant Iherzolite and Mesozoic marble clasts. These series are topped by Late Cretaceous flyschs [e.g., Lagabrielle and Bodinier, 2008; Lagabrielle et al., 2010; Clerc et al., 2012]. While Turonian-Senonian flyschs reached temperatures of $350^{\circ} \mathrm{C}$ [Clerc et al., 2015] and are ductily deformed in the Aulus basin, only the pre-Cenomanian strata are affected by penetrative ductile deformations north of the Aulus basin (Figure 4).

The $3 \mathrm{~S}$ crystalline massif consists of Cambrian to Silurian metasedimentary rocks intruded by several plutons, namely, from west to east, the Ercé granite, the Garrassoula leucogranite, the $3 S$ granite, and the 35 migmatite (Figure 3). The Oust-Massat basin is composed of up to $400 \mathrm{~m}$ thick nonmetamorphic Cenomanian to Coniacian sedimentary rocks (Flyschs à Fucoïdes Formation) unconformably overlying the northwestern edge of the 35 Paleozoic massif (Figures 3a, 3b, and 4). Flysch deposits of the Oust-Massat basin reveal no major internal deformation, and the original bedding is everywhere well distinguished (Figure 5). The northern boundary of the Oust-Massat basin, near Soueix, contains reworked granitic breccias and is in tectonic contact with metamorphosed Albian sedimentary rocks of the Saint-Girons basin (Figure 5). The latter connects to the Tarascon basin in the east via an east-west directed narrow corridor, comprising reworked Paleozoic blocks and breccias between the $3 \mathrm{~S}$ and the Arize crystalline massifs. The Tarascon basin is bordered by the $3 \mathrm{~S}$ Paleozoic massif to the west, the Arize Paleozoic massif to the northwest, and the SaintBarthélemy Paleozoic massif to the east. Likewise the Saint-Girons basin, the Tarascon basin is composed of 2 to $2.5 \mathrm{~km}$ of Late Triassic to Late Cretaceous series, which are variably metamorphosed and affected by ductile deformations (Figure 5 ).

The Arize Paleozoic Massif is made of Cambrian to Permian sedimentary clastic successions intruded by two granitic bodies, the Lacourt massif to the southwest and the Foix massif at the eastern edge (Figure 3a). A migmatite body, defined here as the Arize migmatitic massif, occupies the south to southwest part of the massif.

The Mesozoic Nalzen basin is bounded by the Saint Barthélemy Paleozoic massif to the south and by the NPFT to the north. The basin consists in a $2 \mathrm{~km}$ thick unmetamorphosed sedimentary succession ranging from the Late Triassic to the Late Cretaceous.

The Arize Paleozoic Massif is covered to the north by a thick succession $(5-5.5 \mathrm{~km})$ of unmetamorphosed Permo-Triassic to Albo-Cenomanian deposits of the Camarade basin. The Albo-Cenomanian series represent an example of the so-called black flyschs interbedded with pebble lags and breccias bearing Paleozoic clasts [Deségaulx et al., 1990] (Figures 3a and 4). 


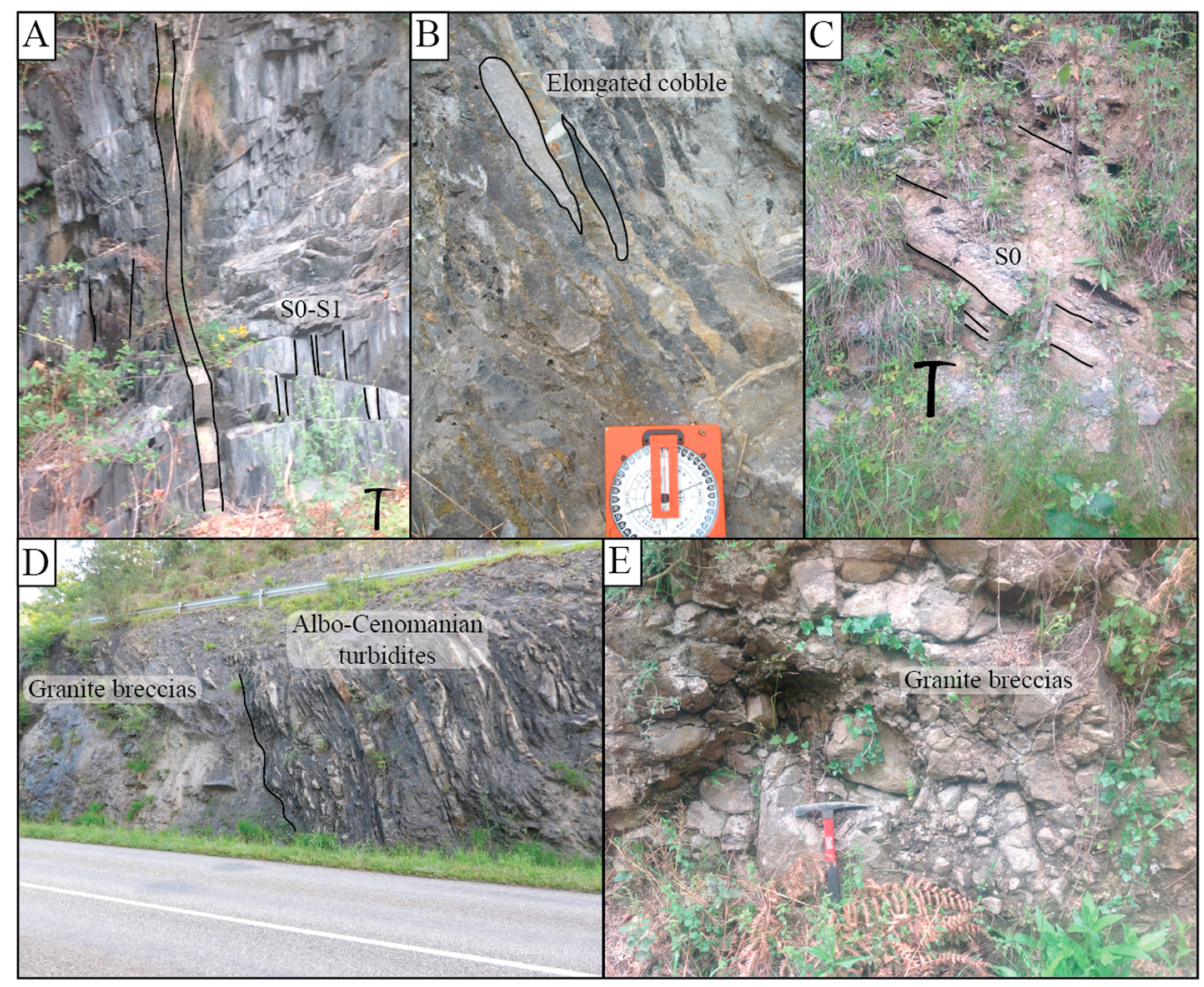

Figure 5. Field photographs of ductile deformations including (a) transported S0 in the regional-scale S1 schistosity and (b) elongated cobbled stretched vertically (Oust-Massat and the Saint-Girons basins) near Soueix. (c) The Cenomanian-Coniacian series of the Oust-Massat basin lie unconformably on the northern edge of the 35 massif and reveal no major tectonic deformation. (d)The contact between the Saint-Girons and the Oust-Massat basins is highlighted by granite breccias reworked in Albo-Cenomanian deposits, in contact with Albo-Cenomanian turbidites in the Saint-Girons basin. (e) These breccias are also reworked in the Cenomanian-Coniacian series of the Oust-Massat basin.

\subsubsection{Existing Low-Temperature Thermochronological and Thermal Constraints on Deformation Patterns}

The first AFT analyses carried out in the northern Pyrenees were performed on several granitic bodies of interest to our study [Yelland, 1991] (Table 1). Two samples were dated on the Lacourt granite massif at $40 \pm 2 \mathrm{Ma}$ and $34 \pm 2 \mathrm{Ma}$. Samples from the $3 \mathrm{~S}$ and the Arize migmatite massifs yielded similar ages at $35 \pm 2 \mathrm{Ma}$ and $43 \pm 3 \mathrm{Ma}$, respectively. The Ercé and the Foix granite massifs were dated at $38 \pm 2 \mathrm{Ma}$ and $106 \pm 5 \mathrm{Ma}$, respectively. A sample of polymict calcareous conglomerate of the Albian Camarade basin yielded an AFT central age of

Table 1. Low-Temperature Thermochronological Data (Age and Elevation) From the NPZ in the Literature

\begin{tabular}{lccc} 
References & Massif & Age (Ma) & Elevation (m) \\
\hline Yelland [1991] & Lacourt & $40 \pm 2$ & 520 \\
(AFT) & Ercé & $34 \pm 2$ & 500 \\
& Foix & $38 \pm 2$ & 945 \\
& Trois-Seigneurs migmatite & $106 \pm 5$ & 455 \\
& Arize migmatite & $35 \pm 2$ & 1350 \\
& Camarade (conglomerate) & $43 \pm 3$ & 505 \\
(ZFT) & Lacourt & $118 \pm 12$ & 440 \\
& Arize migmatite & $71 \pm 3$ & 500 \\
Fitzgerald et al. [1999] & Lacourt & $80 \pm 5$ & 505 \\
(AFT) & & $55 \pm 3$ & 1048 \\
& & $49 \pm 3$ & 950 \\
& & $50 \pm 3$ & 815 \\
& & $49 \pm 2$ & 645 \\
\end{tabular}


$118 \pm 12 \mathrm{Ma}$. ZFT analyses have also been performed on the Lacourt granite and the Arize migmatite massifs showing ages of $71 \pm 3 \mathrm{Ma}$ and $80 \pm 5 \mathrm{Ma}$ [Yelland, 1991].

Fitzgerald et al. [1999] carried out an age elevation profile in the Lacourt granitic massif yielding AFT ages ranging from $49 \pm 2 \mathrm{Ma}$ at $645 \mathrm{~m}$ to $55 \pm 3 \mathrm{Ma}$ at $1048 \mathrm{~m}$ (Table 1). They dated a lowermost sample $(470 \mathrm{~m})$ at $37 \pm 1 \mathrm{Ma}$ that might be off the trend pictured by the higher samples due to faulting. They measured apatite mean track lengths (MTL) in the 13.0-14.1 $\mu \mathrm{m}$ range, similar to those measured in previous studies [Yelland, 1990; Morris et al., 1998].

Fitzgerald et al. [1999] inferred a break-in slope at $950 \mathrm{~m}$ in the age elevation profiles that was interpreted to reflect an exhumational event. They concluded that exhumation of the NPZ started at $\sim 50 \mathrm{Ma}$ at a rate of $\sim 0.2 \mathrm{~km} /$ Myr. However, Sinclair et al. [2005] pointed out that these data are also consistent with a slower exhumation from $\sim 60 \mathrm{Ma}$ accelerating only after $\sim 40 \mathrm{Ma}$. Thus, the existing bedrock thermochronological data seem to bring no clear resolution on the thermal history of the north Pyrenean crystalline massifs before $50 \mathrm{Ma}$. By contrast, detrital fission track and (U-Th)/He ages performed on Cenozoic sediments of the northern foreland succession [Mouthereau et al., 2014] and in the southern Pyrenees [Beamud et al., 2011; Whitchurch et al., 2011; Filleaudeau et al., 2011] show consistent results that revealed a cooling event as old as 70-75 Ma.

Raman spectroscopy on carbonaceous materials (RSCM) analyses performed on Mesozoic sedimentary rocks indicate that these rocks experienced temperatures ranging from $\sim 200^{\circ} \mathrm{C}$ (Camarade and Oust-Massat basins) to $\sim 350^{\circ} \mathrm{C}$ (Saint-Girons basin, Tarascon basin) and even up to $500-600^{\circ} \mathrm{C}$ (Aulus basin) [Clerc et al., 2015] (Figure 3a and Table S1 in the supporting information). Sharp discontinuities in peak temperatures from 350 to $500-600^{\circ} \mathrm{C}$ are observed between the Aulus and Saint-Girons basins for the same stratigraphic units. This may reveal a relatively large overthrusting of Mesozoic units with higher original temperature over cooler units or instead reflect the configuration of originally close domains of the rifted margin characterized by highly variable geothermal gradients [Vacherat et al., 2014]. Which of these mechanisms is the prime factor controlling the temperature pattern is yet to be constrained.

It must be noted that ductile deformations are not restricted to the Aulus basin. They are also recognized in the Triassic, Jurassic, and Early Cretaceous sedimentary successions of the Saint-Girons and the Tarascon basins. This suggests that a large zone characterized by variable peak temperatures are affected by a similar deformation pattern. Recent new ${ }^{40} \mathrm{Ar}-{ }^{39} \mathrm{Ar}$ dates on muscovite and amphibole in metasediments (marbles and metapelites) and magmatic rocks of the Aulus basin confirm cooling events at 89-100 Ma (Albian to Turonian) [Clerc et al., 2015]. These ages indicate cooling from temperatures of $400^{\circ} \mathrm{C}$ (muscovite) to $550^{\circ} \mathrm{C}$ (amphibole) below the RSCM temperature and therefore likely postdate the age of peak metamorphism that is related to crustal breakup and mantle exhumation. Taken together, these data suggest that the timing of ductile deformation in the temperature range of $600-200^{\circ} \mathrm{C}$ postdates by at least $10 \mathrm{Myr}$ the timing of mantle exhumation and is therefore not necessarily related only to extension but may also be linked with subsequent shortening. This is in accord with thermal models from the western Pyrenees that indicate temperatures of nearly $200^{\circ} \mathrm{C}$ maintained 20-30 Myr after onset of shortening [Vacherat et al., 2014]. Because the hyperextended domain of the paleomargin was shorter in the Ariège orogenic segment, the isothermal phase may have been reduced [Mouthereau et al., 2014]. Field data and microstructural constraints on strain distribution are still needed here to conclude on the tectonic origin and the temporal evolution of the ductile deformations.

\section{Sampling Strategy and Low-Temperature Thermochronological Analyses}

We collected 13 bedrock samples (Figure 3a) from the Ercé (Erc-1) and the Garrassoula plutons (Mas-1) in the $3 \mathrm{~S}$ massifs, from the Lacourt (Lac-1 and Lac-2) and Foix plutons (Foi-1), and from the Arize migmatite (Bou-1) in the Arize massif. A new vertical profile was sampled on the 35 granitic massif from $1459 \mathrm{~m}$ to $2199 \mathrm{~m}$ elevation (3S-1 to 3S-7; Table 2 and Figure 3). We also collected one detrital sample from the black flysch Formation of the Camarade basin (Cmd-1).

All samples were prepared at Centre de Recherches Pétrographiques et Géochimiques (CRPG) (Nancy, France). They were crushed, and zircon and apatite grains were separated for low-temperature thermochronological analyses using standard heavy-liquid and magnetic separation techniques for the $61-280 \mu \mathrm{m}$ fraction. 
Table 2. Analytical Results for AFT Analyses Performed on Ariège Massifs ${ }^{a}$

\begin{tabular}{|c|c|c|c|c|c|c|c|c|c|c|c|c|}
\hline Sample & $\begin{array}{l}\text { Latitude } \\
\qquad\left({ }^{\circ} \mathrm{N}\right)\end{array}$ & $\begin{array}{c}\text { Longitude } \\
\left({ }^{\circ} \mathrm{E}\right)\end{array}$ & $\begin{array}{l}\text { Altitude } \\
\text { (m) }\end{array}$ & $\begin{array}{c}\text { Nb Compted } \\
\text { Grain }\end{array}$ & $\begin{array}{c}P\left(\chi^{2}\right) \\
(\%)\end{array}$ & $\begin{array}{c}\text { Dispersion } \\
\text { (\%) }\end{array}$ & $\begin{array}{c}\text { Central Age } \\
\text { (Ma) }\end{array}$ & $\begin{array}{l}\text { Error } \\
(1 \sigma)\end{array}$ & $\begin{array}{c}\mathrm{Nb} \\
\text { Lengths }\end{array}$ & $\begin{array}{c}\text { MTL } \\
(\mathrm{m})\end{array}$ & $\begin{array}{l}\text { Error } \\
(1 \sigma)\end{array}$ & $\begin{array}{c}\text { Mean } \\
\text { Dpar }\end{array}$ \\
\hline $3 S-1$ & $42^{\circ} 49^{\prime} 49.88^{\prime \prime}$ & $1^{\circ} 26^{\prime} 24.48^{\prime \prime}$ & 2199 & 20 & 94 & 0 & 46.5 & 4.7 & 15 & 14.1 & 1.1 & 1.7 \\
\hline $3 S-2$ & $42^{\circ} 49^{\prime} 37.95^{\prime \prime}$ & $1^{\circ} 26^{\prime} 24.32^{\prime \prime}$ & 2068 & 22 & 98 & 0 & 37.0 & 2.2 & 48 & 13.2 & 1.1 & 1.8 \\
\hline $3 S-3$ & $42^{\circ} 49^{\prime} 24.71^{\prime \prime}$ & $1^{\circ} 26^{\prime} 27.59^{\prime \prime}$ & 1915 & 20 & 99 & 0 & 46.4 & 4.0 & 13 & 13.9 & 1.6 & 2.2 \\
\hline $3 S-4$ & $42^{\circ} 49^{\prime} 14.16^{\prime \prime}$ & 1²6'19.64" & 1772 & 27 & 89 & 0 & 37.6 & 2.4 & 28 & 14.2 & 1.0 & 2.0 \\
\hline $3 S-5$ & $42^{\circ} 49^{\prime} 4.63^{\prime \prime}$ & 1²6'8.84" & 1700 & 31 & 95 & 0 & 35.4 & 2.4 & 27 & 13.4 & 1.2 & 1.9 \\
\hline $3 S-6$ & $42^{\circ} 48^{\prime} 46.23^{\prime \prime}$ & $1^{\circ} 26^{\prime} 13.79^{\prime \prime}$ & 1598 & 20 & 45 & 0 & 41.8 & 1.9 & 34 & 13.6 & 0.9 & 2.2 \\
\hline $3 S-7$ & $42^{\circ} 48^{\prime} 19.77^{\prime \prime}$ & $1^{\circ} 56^{\prime} 29.44^{\prime \prime}$ & 1459 & 27 & 95 & 0 & 41.5 & 3.4 & 16 & 13.8 & 1.1 & 1.9 \\
\hline Erc-1 & $42^{\circ} 51^{\prime} 37.53^{\prime \prime}$ & $1^{\circ} 14^{\prime} 50.05^{\prime \prime}$ & 552 & 20 & 39 & 5 & 39.1 & 1.9 & 42 & 13.9 & 1.1 & 2.4 \\
\hline Lac-1 & $42^{\circ} 56^{\prime} 3.10^{\prime \prime}$ & $1^{\circ} 10^{\prime} 36.54^{\prime \prime}$ & 451 & 56 & 93 & 0 & 43.9 & 2.1 & 16 & 13.5 & 1.2 & 1.6 \\
\hline Lac-2 & $42^{\circ} 54^{\prime} 28.08^{\prime \prime}$ & $1^{\circ} 12^{\prime} 49.37^{\prime \prime}$ & 493 & 31 & 17 & 10 & 38.5 & 1.8 & 159 & 13.5 & 1.2 & 2.2 \\
\hline Foi-1 & $42^{\circ} 57^{\prime} 52.71^{\prime \prime}$ & $1^{\circ} 31^{\prime} 58.12^{\prime \prime}$ & 488 & 29 & 98 & 0 & 74.9 & 1.2 & 52 & 13.0 & 1.6 & 1.6 \\
\hline
\end{tabular}

${ }^{\mathrm{a}}$ Fission track age is given as Central Age [Galbraith and Laslett, 1993]. Samples were counted dry with a BH-2 Olympus microscope at $1250 \mathrm{X}$ magnification. Ages

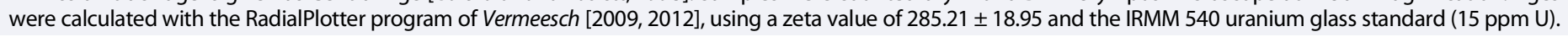

\subsection{Apatite and Zircon Fission Track Analyses}

Apatite and zircon grains were prepared for fission track dating and analyzed at the thermochronology laboratory of ISTerre (Université Joseph Fourier, Grenoble). Apatite grains were mounted in epoxy, polished to expose internal crystal surfaces, and etched with $5.5 \mathrm{M} \mathrm{HNO}_{3}$ for $20 \mathrm{~s}$ at $21^{\circ} \mathrm{C}$. Zircon grains were mounted in a teflon sheet, polished, and etched with $\mathrm{NaOH}-\mathrm{KOH}$ at $228^{\circ} \mathrm{C}$ between 8 and $13 \mathrm{~h}$. Using the external detector method [Gleadow et al., 1976], mica sheets were attached to all samples and irradiated with thermal neutrons at the FRM II Research Reactor of the Technische Universität München (Germany) with IRMM 540R and CN1 dosimeter glasses for apatite and zircon respectively, and with Durango and Fish Canyon Tuff age standards for apatite and Buluk Tuff and Fish Canyon Tuff for zircon. After irradiation, mica detectors were etched in $48 \% \mathrm{HF}$ at $21^{\circ} \mathrm{C}$ for $18 \mathrm{~min}$. Counting was carried out at $1250 \mathrm{X}$ on an Olympus BH2 optical microscope using FTStage 4.04 system of Dumitru [1993]. Individual fission track ages were obtained using zeta factors following the approach of Hurford and Green [1983]. We measured horizontal confined track lengths and track etch pit size to determine the Dpar value for all apatite samples.

\subsection{Zircon (U-Th-Sm)/He Analyses}

One hundred detrital zircon grains of sample $\mathrm{Cmd}-1$ were mounted in epoxy and polished for $\mathrm{U} / \mathrm{Pb}$ analyses [Vacherat, 2014]. Among them, a total of 35 zircon grains characteristic of individual U/Pb age peaks distribution were retrieved for (U-Th-Sm)/He analysis. For bedrock (U-Th-Sm)/He analysis, three single zircon grains were selected per sample. We choose prismatic to round-shaped grains, zero to two pyramids, with an equivalent spherical radius ranging from $60 \mu \mathrm{m}$ to $110 \mu \mathrm{m}$. All zircon grains were then measured and loaded in Pt capsules for He extraction at CRPG. They were outgassed at $1500^{\circ} \mathrm{C}$ for $20 \mathrm{~min}$ and analyzed for He concentrations with a VG603 noble gas mass spectrometer [Pik et al., 2003; Godard et al., 2009]. After total helium extraction, Pt capsules containing zircon grains were retrieved for $U$, Th, and Sm content measurements at Service d'Analyse des Roches et des Minéraux (SARM, Nancy, France), following the procedure developed by Tibari et al. [2016]. The overall precision of He ages determined with this procedure is within $5-6 \%(1 \sigma)$. Zircon grains whose $\mathrm{He}$ and/or $U$ concentrations are below the limit of quantification (e.g., less than $1.10^{-13}$ moles for He content and less than $100 \mathrm{ppb}$ for $U$ concentration in the solution after blank correction) were not considered for this study (see Tibari et al. [2016] for details). Zircon ages were corrected for $\alpha$ ejection $\left(F_{T}\right)$ following Ketcham et al. [2011]. To account for our polishing (abrasion) of the detrital zircon single grains, we consider that we removed between $\sim 20 \mu \mathrm{m}$ (the mean stopping distance of Ketcham et al. [2011]) and the half of the mean width of our zircon grains $(\sim 45 \mu \mathrm{m})$. Following Reiners et al. [2007], we corrected $F_{T}$ considering an abrasion of $45 \mu \mathrm{m}$ for each detrital grain.

\subsection{Apatite (U-Th-Sm)/He Analysis}

We performed AHe analyses at Paris-Sud University (Orsay, France) following the procedure described by Fillon et al. [2013]. Selected apatite grains were prismatic, with zero to two pyramids and with an equivalent spherical radius ranging from $50 \mu \mathrm{m}$ to $150 \mu \mathrm{m}$. One to four single-grain replicates per sample were analyzed 

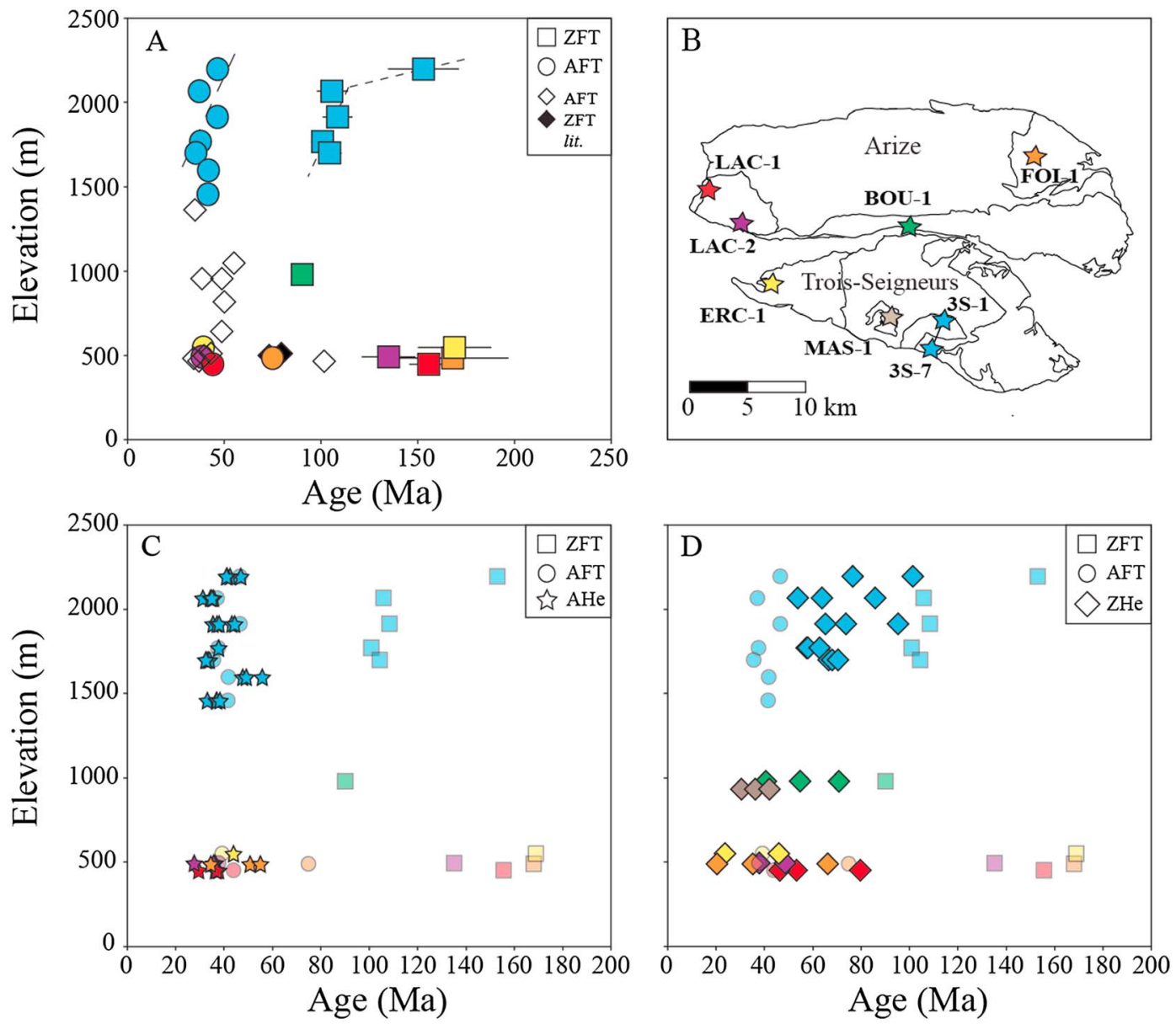

Figure 6. Thermochronological data collected in the study area from our granite samples. (b) The samples to which a color is associated. (a) AFT and ZFT ages are compared to AFT (empty diamonds) and to ZFT data (black diamonds) from the literature [Yelland, 1991; Fitzgerald et al., 1999] (Table 1). (c) AHe ages from Arize and 35 massifs are younger or in the range of AFT ages. (d) ZHe ages from the Arize and 3 S massifs are bounded by ZFT and AFT ages.

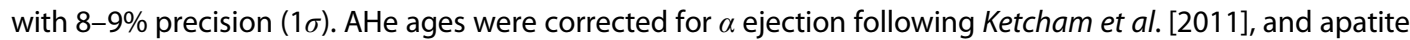
grains with outlier Th/U ratios were excluded as they potentially bear small zircon or monazite inclusions.

\section{Results}

\subsection{The 3S-Profile}

$\mathrm{AHe}$ and AFT analyses from the $3 \mathrm{~S}$ profile (3S-1 to 3S-7) yielded consistent synorogenic ages ranging from $31.1 \pm 2.5 \mathrm{Ma}$ to $55.8 \pm 4.5 \mathrm{Ma}$ and ages from $35.4 \pm 2.4 \mathrm{Ma}$ to $46.5 \pm 4.7 \mathrm{Ma}$, respectively, without clear dependence on altitude (Figures $6 a$ and $6 c$ and Tables 2, 4, and S2). This result suggests a monotonic cooling that is consistent with the unimodal distribution of mean track lengths (MTL) ranging from $13.2 \mu \mathrm{m}$ to $14.2 \mu \mathrm{m}$ (Figure 7 and Table 2). Samples 3S-6 and 3S-7 yielded no zircons grains. ZHe data show a larger age distribution between $53.7 \mathrm{Ma}$ and $101.4 \mathrm{Ma}$, spreading from AFT to ZFT data (Figure $6 \mathrm{~d}$ and Table 5). There exists a general negative correlation between ZHe ages and the effective uranium concentration $(\mathrm{eU}, \mathrm{eU}=\mathrm{U}=+0.235 \times \mathrm{Th}$ ), which is exhibited by grains from individual samples (see Figure S1). Such individual patterns are clustered for samples that apparently experienced a similar thermal history (Figure 9) and define two distinct trends: one for the higher altitude samples (1900-2200 m) with the oldest ages and one for the lower altitude samples $(\sim 1700 \mathrm{~m})$ with younger ages at equivalent eU (Figure 9). Date-eU correlations have already been observed and interpreted as due to differential damage-dependent sensitivity to diffusion [Reiners, 2005; Guenthner et al., 2013, 2014] and therefore could represent a continuous range of thermochronologic ages recorded over cooling spreading from ZFT to AFT 


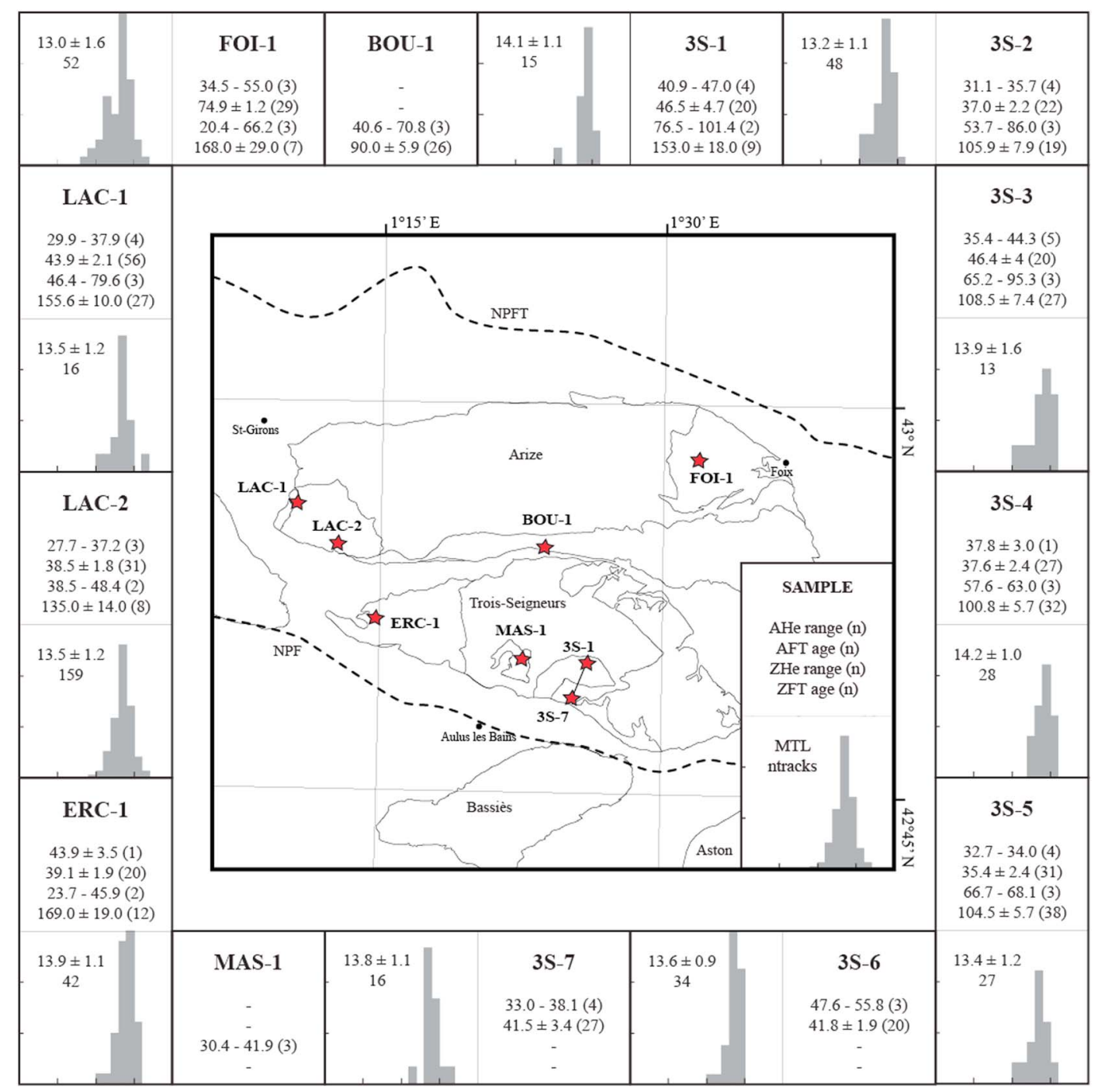

Figure 7. Synthesis of thermochronological analyses performed on granite samples in the Ariège area indicating the $\mathrm{AHe}$, AFT, ZHe, and ZFT age range and number of dated grains for each sample, including apatite MTL measurements.

thermal sensitivities. Distribution of ZFT ages with elevation suggests a break-in slope at $2068 \mathrm{~m}$ elevation. The highest sample shows an age of $153.0 \pm 18.0 \mathrm{Ma}$ (3S-1), whereas the lowest samples show ages that are distinctively younger, ranging from 108.5 \pm 7.4 Ma to 100.8 \pm 5.7 Ma (Figure 6a and Tables 3 and S3).

\subsection{The 35 Massif Unit}

For the Erc-1 sample, AHe analyses yielded a unique grain age of $43.9 \pm 3.5 \mathrm{Ma}$ (Figure $6 \mathrm{c}$ and Table 4). AFT analyses on Erc-1 show an age of $39.1 \pm 1.9 \mathrm{Ma}$ and a unimodal distribution of track lengths with a MTL of $13.9 \pm 1.1 \mu \mathrm{m}$ (Figures $6 \mathrm{a}$ and 7 and Tables 2 and S2). Two ZHe ages at $45.9 \pm 2.8 \mathrm{Ma}$ and $23.7 \pm 1.4 \mathrm{Ma}$ are associated with eU concentrations of $\sim 530 \mathrm{ppm}$ and $\sim 3040 \mathrm{ppm}$, respectively (Figures $6 \mathrm{~d}$ and $\mathrm{S} 1$ and Table 5).Without defining a specific trend (Figure S1), they could extend the low-altitude 35 date-eU trend toward very high eU (Figure 9). ZFT data yielded a preorogenic age of 169.0 $19.0 \mathrm{Ma}$ (Figure 6a and Tables 3 and S3).

In the Mas-1 sample (Garrassoula granite) we successfully performed ZHe analyses and obtained ZHe ages ranging from $30.4 \pm 1.8 \mathrm{Ma}$ to $40.9 \pm 2.5 \mathrm{Ma}$. They are, however, only associated with very high eU concentrations $>2700$ ppm (Figure S1 and Table 5) and therefore plot at the extreme end of any date-eU correlations (Figure 9). The lack of apatite grains and of a sufficient number of zircon grains did not allow for AHe, AFT, or ZFT analyses. 
Table 3. Analytical Results for ZFT Analyses Performed on Ariège Massifs ${ }^{\mathrm{a}}$

\begin{tabular}{lcccccccc} 
Sample & $\begin{array}{c}\text { Latitude } \\
\left({ }^{\circ} \mathrm{N}\right)\end{array}$ & $\begin{array}{c}\text { Longitude } \\
\left({ }^{\circ} \mathrm{E}\right)\end{array}$ & $\begin{array}{c}\text { Altitude } \\
(\mathrm{m})\end{array}$ & $\begin{array}{c}\text { Nb compted } \\
\text { grain }\end{array}$ & $\begin{array}{c}P\left(\chi^{2}\right) \\
(\%)\end{array}$ & $\begin{array}{c}\text { Dispersion } \\
(\%)\end{array}$ & $\begin{array}{c}\text { Central age } \\
(\mathrm{Ma})\end{array}$ & Error $(1 \sigma)$ \\
\hline $3 \mathrm{~S}-1$ & $42^{\circ} 49^{\prime} 49.88^{\prime \prime}$ & $1^{\circ} 26^{\prime} 24.48^{\prime \prime}$ & 2199 & 9 & 29 & 7 & 153.0 & 18.0 \\
$3 \mathrm{~S}-2$ & $42^{\circ} 49^{\prime} 37.95^{\prime \prime}$ & $1^{\circ} 26^{\prime} 24.32^{\prime \prime}$ & 2068 & 19 & 56 & 0 & 105.9 & 7.9 \\
$3 \mathrm{~S}-3$ & $42^{\circ} 49^{\prime} 24.71^{\prime \prime}$ & $1^{\circ} 26^{\prime} 27.59^{\prime \prime}$ & 1915 & 27 & 46 & 9 & 108.5 & 7.4 \\
$3 \mathrm{~S}-4$ & $42^{\circ} 49^{\prime} 14.16^{\prime \prime}$ & $1^{\circ} 26^{\prime} 19.64^{\prime \prime}$ & 1772 & 32 & 85 & 0 & 100.8 & 5.7 \\
$3 \mathrm{~S}-5$ & $42^{\circ} 49^{\prime} 4.63^{\prime \prime}$ & $1^{\circ} 26^{\prime} 8.84^{\prime \prime}$ & 1700 & 38 & 73 & 0 & 104.5 & 5.7 \\
Erc-1 & $42^{\circ} 51^{\prime} 37.53^{\prime \prime}$ & $1^{\circ} 14^{\prime} 50.05^{\prime \prime}$ & 552 & 12 & 92 & 0 & 169.0 & 19.0 \\
Lac-1 & $42^{\circ} 56^{\prime} 3.10^{\prime \prime}$ & $1^{\circ} 10^{\prime} 36.54^{\prime \prime}$ & 451 & 27 & 98 & 0 & 155.6 & 10.0 \\
Lac-2 & $42^{\circ} 54^{\prime} 28.08^{\prime \prime}$ & $1^{\circ} 12^{\prime} 49.37^{\prime \prime}$ & 493 & 8 & 89 & 0 & 135.0 & 14.0 \\
Foi-1 & $42^{\circ} 57^{\prime} 52.71^{\prime \prime}$ & $1^{\circ} 31^{\prime} 58.12^{\prime \prime}$ & 488 & 7 & 96 & 0 & 168.0 & 29.0 \\
Bou-1 & $42^{\circ} 54^{\prime} 27.06^{\prime \prime}$ & $1^{\circ} 23^{\prime} 43.92^{\prime \prime}$ & 981 & 26 & 31 & 0 & 90.0 & 5.9 \\
Cmd-1 & $43^{\circ} 5^{\prime} 8.11^{\prime \prime}$ & $1^{\circ} 16^{\prime} 45.04^{\prime \prime}$ & 589 & 24 & 92 & 0 & $\mathrm{P} 1: 218.0$ & 22.0 \\
\hline
\end{tabular}

${ }^{\mathrm{a}}$ Fission track age is given as Central Age [Galbraith and Laslett, 1993]. Samples were counted dry with a BH-2 Olympus microscope at 1250X magnification. Ages were calculated with the RadialPlotter program of Vermeesch [2009, 2012], using a zeta value of $141.69 \pm 4.66$ and the CN1 uranium glass standard ( $39.8 \mathrm{ppm} \mathrm{U)}$.

\subsection{Arize Massif Unit}

Two samples from the Lacourt massif (Lac-1 and Lac-2) were analyzed for AHe, AFT, ZHe, and ZFT dating. AHe ages range from $37.9 \pm 3.0 \mathrm{Ma}$ (LaC-1) to $27.7 \pm 2.2 \mathrm{Ma}$ (Lac-2) and are slightly younger than AFT ages of $43.9 \pm 2.1 \mathrm{Ma}$ to $38.5 \pm 1.8 \mathrm{Ma}$, respectively (Figures $6 \mathrm{a}$ and $6 \mathrm{c}$ and Tables 2, 4, and S2). Measured track lengths show a unimodal distribution centered at $13.5 \pm 1.2 \mu \mathrm{m}$ (Figure 7 and Tables 2 and S2). ZHe ages from Lac- 1 and Lac-2 samples display ages from $38.5 \pm 2.3$ to $48.4 \pm 2.9 \mathrm{Ma}$ and from $46.4 \pm 2.8$ to $79.6 \pm 4.8 \mathrm{Ma}$, respectively, which are associated with eU concentrations ranging from $\sim 200$ ppm to $\sim 600$ ppm (Figure S1 and Table 5). ZHe data from the Lac-2 sample exhibit an internal negative correlation with eU (Figure S1), and both Lac samples are clustered and superimposed on the low-altitude 35 correlation suggesting that they could have expericencd the same thermal history. ZFT analyses yield consistent preorogenic ages of $155.6 \pm 10.0 \mathrm{Ma}$ and $135.0 \pm 14.0 \mathrm{Ma}$, respectively (Figure 6a and Tables 3 and S3).

AHe ages obtained on the Foix granite (Foi-1) range from $34.5 \pm 2.8 \mathrm{Ma}$ to $55 \pm 4.4 \mathrm{Ma}$ that are younger than an AFT age of $74.9 \pm 1.2 \mathrm{Ma}$ (Figures $6 \mathrm{a}$ and $6 \mathrm{c}$ and Tables 2,4 , and S2). Measured track lengths show a unimodal distribution with a MTL of $13.0 \pm 1.6 \mu \mathrm{m}$ (Figure 7 and Tables 2 and S2). ZHe data show ages at $20.4 \pm 1.2 \mathrm{Ma}$ and $35.3 \pm 2.1 \mathrm{Ma}$ that are associated with eU concentrations higher than $2500 \mathrm{ppm}$ and an older age at 66.2 $\pm 4.0 \mathrm{Ma}$, corresponding to a lower eU concentration <1000 ppm (Figure S1 and Table 5). ZFT analyses yielded a preorogenic age of $168.0 \pm 29.0 \mathrm{Ma}$ (Figure $6 \mathrm{a}$ and Tables 3 and S3). ZHe data from Bou-1 sample in the Arize migmatite yielded ages ranging from 40.6 $2.4 \mathrm{Ma}$ to $70.8 \pm 4.2 \mathrm{Ma}$ associated with eU concentrations $<1000$ ppm (Figure S1 and Table 5), which surprisingly define a positive correlation orthogonal to all other apparent trends observed for samples measured in this study. ZFT data yield an age of $90.0 \pm 5.9 \mathrm{Ma}$ (Figure $6 \mathrm{a}$ and Tables 3 and S3).

\subsection{Camarade Basin}

ZHe analyses performed on black flysch sample (Cmd-1, 100 Ma) yielded 18 ages, which are ranging from $\sim 97 \mathrm{Ma}$ to $\sim 229 \mathrm{Ma}$ (Figure 8a). The 24 ZFT ages are ranging between $\sim 104 \mathrm{Ma}$ and $\sim 446 \mathrm{Ma}$ (Figure 8b). Hence, most of the ZHe ages and all the ZFT ages are preorogenic and are older than the depositional age. We interpret these samples as unreset. Using the Kernel density distribution of the DensityPlotter program of Vermeesch [2009, 2012], we decomposed our age distribution into two age components (errors are given as $\pm 1 \sigma$ ) at $124.0 \pm 4.0$ (P1, 67\%) and $202.0 \pm 9.0$ (P2,33\%) for the ZHe data and one age component at $218.0 \pm 24.0 \mathrm{Ma}$ for ZFT data (Figure 8 and Tables 6 and S3).

\section{Data Modeling Approach}

\subsection{QTQt Modeling of Low-Temperature Thermochronological Data}

To determine the thermal history from our multithermochronometer approach, we inverse modeled our data using QTQt [Gallagher et al., 2009; Gallagher, 2012]. The inversion procedure determines the most robust 
Table 4. Analytical Results for AHe Analyses Performed on Ariège Massifs ${ }^{a}$

\begin{tabular}{|c|c|c|c|c|c|c|c|c|c|c|c|c|c|c|c|c|}
\hline Sample & Aliquot & $\begin{array}{l}\text { Weight } \\
(\mu \mathrm{g})\end{array}$ & $\begin{array}{c}W \\
(\mu \mathrm{m})\end{array}$ & $\begin{array}{c}L \\
(\mu \mathrm{m})\end{array}$ & $\begin{array}{c}H \\
(\mu \mathrm{m})\end{array}$ & Geometry & $\begin{array}{c}\text { Rs } \\
(\mu \mathrm{m})\end{array}$ & $\begin{array}{c}{\left[{ }^{4} \mathrm{He}\right]} \\
(\mathrm{nmol} / \mathrm{g})\end{array}$ & $\begin{array}{c}{[\mathrm{U}]} \\
(\mathrm{ppm})\end{array}$ & $\begin{array}{c}{[\mathrm{Th}]} \\
(\mathrm{ppm})\end{array}$ & $\begin{array}{l}{[\mathrm{Sm}]} \\
(\mathrm{ppm})\end{array}$ & $\begin{array}{c}\mathrm{eU} \\
\text { (ppm) }\end{array}$ & $F_{T}$ & $\begin{array}{c}\text { Measured } \\
\text { Age (Ma) }\end{array}$ & $\begin{array}{l}\text { Corrected } \\
\text { Age (Ma) }\end{array}$ & $\begin{array}{l}\text { Error } \\
(1 \sigma)\end{array}$ \\
\hline \multirow[t]{4}{*}{$3 S-1$} & A & 9.0 & 138 & 125 & 263 & $1 p+1 b f$ & 82 & 6.42 & 27 & 33 & 43 & 35 & 0.8 & 34.0 & 41.3 & 3.3 \\
\hline & B & 6.2 & 125 & 125 & 213 & $1 p+1 b f$ & 75 & 9.14 & 36 & 37 & 53 & 44 & 0.8 & 38.0 & 47.0 & 3.8 \\
\hline & $\mathrm{C}$ & 9.3 & 125 & 163 & 138 & $2 b f$ & 85 & 5.14 & 21 & 29 & 35 & 28 & 0.8 & 33.8 & 40.9 & 3.3 \\
\hline & $\mathrm{D}$ & 5.6 & 125 & 125 & 263 & $2 \mathrm{bf}$ & 87 & 5.25 & 21 & 28 & 42 & 27 & 0.8 & 35.3 & 42.4 & 3.4 \\
\hline \multirow[t]{4}{*}{$3 S-2$} & A & 5.3 & 125 & 125 & 150 & $2 b f$ & 85 & 5.59 & 32 & 36 & 40 & 40 & 0.8 & 25.7 & 31.1 & 2.5 \\
\hline & B & 5.1 & 125 & 113 & 225 & $2 p$ & 65 & 11.29 & 64 & 60 & 56 & 79 & 0.8 & 26.6 & 34.2 & 2.7 \\
\hline & $\mathrm{C}$ & 8.0 & 163 & 150 & 188 & $1 p+1 b f$ & 90 & 9.39 & 47 & 46 & 42 & 58 & 0.8 & 30.0 & 35.7 & 2.9 \\
\hline & $\mathrm{D}$ & 9.7 & 138 & 150 & 300 & $2 p$ & 78 & 10.59 & 56 & 52 & 49 & 69 & 0.8 & 28.5 & 35.1 & 2.8 \\
\hline \multirow[t]{5}{*}{$3 S-3$} & $A$ & 20.0 & 188 & 188 & 250 & $2 \mathrm{bf}$ & 127 & 3.56 & 15 & 20 & 25 & 20 & 0.9 & 32.7 & 37.0 & 3.0 \\
\hline & B & 15.8 & 175 & 150 & 250 & $2 b f$ & 82 & 5.49 & 23 & 18 & 23 & 27 & 0.9 & 37.6 & 43.2 & 3.5 \\
\hline & $C$ & 2.5 & 88 & 100 & 188 & $2 p$ & 49 & 12.83 & 61 & 58 & 54 & 75 & 0.7 & 31.5 & 44.3 & 3.5 \\
\hline & $\mathrm{D}$ & 2.7 & 113 & 113 & 163 & $2 p$ & 54 & 6.92 & 37 & 37 & 39 & 46 & 0.7 & 28.0 & 38.0 & 3.0 \\
\hline & $E$ & 5.6 & 125 & 138 & 188 & $1 p+1 b f$ & 75 & 4.68 & 24 & 28 & 39 & 30 & 0.8 & 28.5 & 35.4 & 2.8 \\
\hline $3 S-4$ & $A$ & 3.8 & 100 & 113 & 188 & $1 p+1 b f$ & 62 & 6.13 & 32 & 29 & 16 & 39 & 0.8 & 29.1 & 37.8 & 3.0 \\
\hline \multirow[t]{4}{*}{$3 S-5$} & $A$ & 2.8 & 100 & 88 & 163 & $1 p+1 b f$ & 58 & 4.73 & 30 & 20 & 17 & 34 & 0.8 & 25.6 & 34.0 & 2.7 \\
\hline & B & 4.3 & 100 & 100 & 188 & $2 b f$ & 68 & 4.50 & 26 & 24 & 30 & 32 & 0.8 & 26.2 & 33.4 & 2.7 \\
\hline & $C$ & 3.0 & 100 & 100 & 163 & $1 p+1 b f$ & 60 & 8.75 & 56 & 28 & 32 & 63 & 0.8 & 25.8 & 33.9 & 2.7 \\
\hline & $\mathrm{D}$ & 2.3 & 88 & 100 & 150 & $1 p+1 b f$ & 54 & 5.97 & 37 & 36 & 36 & 46 & 0.7 & 24.0 & 32.7 & 2.6 \\
\hline \multirow[t]{4}{*}{$3 S-6$} & $A$ & 36.7 & 225 & 250 & 300 & $2 b f$ & 155 & 20.48 & 87 & 3 & 29 & 88 & 0.9 & 43.0 & 47.6 & 3.8 \\
\hline & B & 57.0 & 300 & 250 & 313 & $2 \mathrm{bf}$ & 192 & 22.43 & 80 & 3 & 21 & 81 & 0.9 & 51.5 & 55.8 & 4.5 \\
\hline & $C$ & 56.7 & 288 & 313 & 288 & $2 b f$ & 198 & 16.12 & 65 & 5 & 19 & 66 & 0.9 & 45.3 & 49.0 & 3.9 \\
\hline & $D$ & 32.7 & 225 & 238 & 275 & $2 b f$ & 154 & 5.39 & 1 & 117 & 15 & 29 & 0.9 & 35.1 & 38.8 & 3.1 \\
\hline \multirow[t]{4}{*}{$3 S-7$} & $A$ & 15.4 & 163 & 188 & 238 & $2 \mathrm{bf}$ & 113 & 4.31 & 20 & 18 & 24 & 25 & 0.9 & 32.1 & 36.9 & 3.0 \\
\hline & B & 6.3 & 125 & 113 & 188 & $2 b f$ & 82 & 4.89 & 23 & 27 & 26 & 29 & 0.8 & 30.7 & 37.4 & 3.0 \\
\hline & $\mathrm{C}$ & 6.1 & 113 & 113 & 213 & $2 b f$ & 76 & 3.21 & 19 & 13 & 16 & 22 & 0.8 & 26.7 & 33.0 & 2.6 \\
\hline & $\mathrm{D}$ & 5.7 & 138 & 138 & 175 & $1 p+1 b f$ & 79 & 8.18 & 39 & 38 & 47 & 48 & 0.8 & 31.2 & 38.1 & 3.1 \\
\hline Erc-1 & $A$ & 5.8 & 125 & 125 & 163 & $2 b f$ & 85 & 19.90 & 99 & 12 & 37 & 101 & 0.8 & 36.3 & 43.9 & 3.5 \\
\hline \multirow[t]{4}{*}{ Lac-1 } & $A$ & 4.9 & 113 & 100 & 200 & $2 b f$ & 74 & 11.70 & 60 & 61 & 80 & 75 & 0.8 & 28.9 & 36.5 & 2.9 \\
\hline & B & 8.7 & 163 & 150 & 163 & $2 \mathrm{bf}$ & 108 & 2.76 & 11 & 19 & 44 & 16 & 0.9 & 32.3 & 37.6 & 3.0 \\
\hline & $C$ & 11.9 & 150 & 138 & 263 & $2 \mathrm{bf}$ & 99 & 4.36 & 17 & 32 & 47 & 25 & 0.9 & 32.1 & 37.9 & 3.0 \\
\hline & $\mathrm{D}$ & 4.8 & 138 & 113 & 225 & $2 p$ & 68 & 4.10 & 18 & 60 & 69 & 33 & 0.8 & 23.1 & 29.9 & 2.4 \\
\hline \multirow[t]{3}{*}{ Lac-2 } & $A$ & 34.2 & 238 & 313 & 313 & $1 p+1 b f$ & 141 & 16.27 & 90 & 3 & 20 & 90 & 0.9 & 33.3 & 37.2 & 3.0 \\
\hline & B & 32.2 & 263 & 275 & 200 & $2 b f$ & 179 & 8.43 & 60 & 5 & 15 & 62 & 0.9 & 25.4 & 27.7 & 2.2 \\
\hline & $\mathrm{D}$ & 29.6 & 225 & 225 & 325 & $1 p+1 b f$ & 133 & 13.72 & 76 & 7 & 20 & 78 & 0.9 & 32.6 & 36.7 & 2.9 \\
\hline \multirow[t]{4}{*}{ Foi-1 } & A & 12.7 & 150 & 163 & 238 & $2 b f$ & 103 & 6.80 & 36 & 34 & 42 & 44 & 0.8 & 28.8 & 34.5 & 2.8 \\
\hline & B & 6.4 & 163 & 188 & 150 & $1 p+1 b f$ & 88 & 13.99 & 46 & 62 & 71 & 61 & 0.8 & 42.5 & 50.9 & 4.1 \\
\hline & $C$ & 25.7 & 213 & 213 & 250 & $2 b f$ & 144 & 6.57 & 17 & 31 & 35 & 25 & 0.9 & 49.3 & 55.0 & 4.4 \\
\hline & $D$ & 4.4 & 125 & 125 & 200 & $2 p$ & 63 & 68.09 & 84 & 1190 & 248 & 370 & 0.8 & 34.4 & 44.6 & 3.6 \\
\hline
\end{tabular}

${ }^{a}$ The $2 p$ geometry corresponds to grains with two pyramids, $1 p+1 \mathrm{bf}$ means one pyramid and one broken face, and $2 \mathrm{bf}$ means two broken faces. Data in italics correspond to grains with outlier Th/U ratios.

time-temperature history and kinetic parameters of low-temperature thermochronological systems that best reproduce our data, using a Bayesian "Markov chain Monte Carlo" algorithm. It incorporates recent kinetic models for He diffusion in apatite [Flowers et al., 2009; Gautheron et al., 2009] and for track annealing in apatite and zircon [e.g., Ketcham et al., 2007; Tagami et al., 1998; Yamada et al., 2007].

The Tagami et al. [1998] and Yamada et al. [2007] annealing models focus on natural young ( $\leq 21 \mathrm{Ma})$ zircon grains, considered as very low damaged zircon. The closure temperatures calculated for these zircon grains are similar to the ones estimated for zero damaged zircon at $\sim 340^{\circ} \mathrm{C}$ [Rahn et al., 2004; Reiners and Brandon, 2006]. Studies that focus on older zircon grains indicate lower closure temperatures of $\sim 200-250^{\circ} \mathrm{C}$ as zircon grains are highly damaged [Brandon et al., 1998; Garver and Kamp, 2002; Bernet and Garver, 2005; Garver et al., 2005; Bernet, 2009]. Hence, the temperature needed for total or partial reset of ZFT ages clearly depends on the amount of radiation damage, which is related to the age of the grains, and especially the time spent at low temperatures.

In QTQt, only the very low damaged zircon annealing models are available. In case of high damaged zircon annealing studies, indeed, fission track length cannot be measured. Therefore, these studies are not designed 


\begin{tabular}{|c|c|c|c|c|c|c|c|c|c|c|c|c|c|c|c|c|}
\hline Sample & Aliquot & $\begin{array}{l}\text { Weight } \\
(\mu \mathrm{g})\end{array}$ & $\begin{array}{c}W \\
(\mu \mathrm{m})\end{array}$ & $\begin{array}{c}L \\
(\mu \mathrm{m})\end{array}$ & $\begin{array}{c}H \\
(\mu \mathrm{m})\end{array}$ & Geometry & $\begin{array}{l}\text { Rs } \\
(\mu \mathrm{m})\end{array}$ & $\begin{array}{c}{\left[{ }^{4} \mathrm{He}\right]} \\
(\mathrm{nmol} / \mathrm{g})\end{array}$ & $\begin{array}{c}{[\mathrm{U}]} \\
(\mathrm{ppm})\end{array}$ & $\begin{array}{c}{[\mathrm{Th}]} \\
(\mathrm{ppm})\end{array}$ & $\begin{array}{l}{[\mathrm{Sm}]} \\
(\mathrm{ppm})\end{array}$ & $\begin{array}{c}\mathrm{eU} \\
\text { (ppm) }\end{array}$ & $F_{T}$ & $\begin{array}{c}\text { Measured } \\
\text { Age (Ma) }\end{array}$ & $\begin{array}{c}\text { Corrected } \\
\text { Age (Ma) }\end{array}$ & $\begin{array}{l}\text { Error } \\
(1 \sigma)\end{array}$ \\
\hline \multirow[t]{2}{*}{$3 S-1$} & D & 9.4 & 93 & 99 & 283 & $2 p$ & 62 & 155.12 & 323 & 105 & 1 & 348 & 0.8 & 82.8 & 101.4 & 6.1 \\
\hline & $\mathrm{F}$ & 12.4 & 127 & 107 & 275 & $2 p$ & 71 & 305.17 & 864 & 70 & 7 & 880 & 0.8 & 64.4 & 76.5 & 4.6 \\
\hline \multirow[t]{3}{*}{$3 S-2$} & D & 19.9 & 109 & 84 & 502 & $1 p+1 b f$ & 65 & 168.36 & 413 & 115 & 8 & 440 & 0.8 & 71.0 & 86.0 & 5.2 \\
\hline & E & 5.7 & 101 & 76 & 222 & $2 p$ & 54 & 202.75 & 724 & 83 & 1 & 743 & 0.8 & 50.6 & 63.9 & 3.8 \\
\hline & $\mathrm{F}$ & 37.1 & 160 & 157 & 424 & $2 p$ & 100 & 192.97 & 741 & 51 & 3 & 754 & 0.9 & 47.5 & 53.7 & 3.2 \\
\hline \multirow[t]{3}{*}{$3 S-3$} & D & 26.0 & 156 & 150 & 341 & $2 p$ & 93 & 164.49 & 345 & 86 & 5 & 366 & 0.9 & 83.5 & 95.3 & 5.7 \\
\hline & E & 9.5 & 109 & 110 & 243 & $2 p$ & 66 & 260.31 & 869 & 104 & 7 & 893 & 0.8 & 54.1 & 65.2 & 3.9 \\
\hline & $\mathrm{F}$ & 13.7 & 112 & 104 & 325 & $2 p$ & 70 & 197.63 & 558 & 158 & 1 & 596 & 0.8 & 61.7 & 73.7 & 4.4 \\
\hline \multirow[t]{3}{*}{$3 S-4$} & D & 42.9 & 179 & 154 & 391 & $1 p+1 b f$ & 102 & 102.04 & 355 & 55 & 2 & 368 & 0.9 & 51.5 & 58.0 & 3.5 \\
\hline & E & 31.2 & 189 & 180 & 321 & $2 p$ & 103 & 95.40 & 335 & 49 & 5 & 347 & 0.9 & 51.1 & 57.6 & 3.5 \\
\hline & $\mathrm{F}$ & 17.9 & 128 & 98 & 385 & $2 p$ & 73 & 83.41 & 273 & 79 & 4 & 292 & 0.8 & 53.1 & 63.0 & 3.8 \\
\hline \multirow[t]{3}{*}{$3 S-5$} & $\mathrm{D}$ & 18.7 & 164 & 153 & 267 & $2 p$ & 87 & 83.12 & 245 & 68 & 4 & 261 & 0.9 & 59.1 & 68.1 & 4.1 \\
\hline & E & 27.2 & 142 & 149 & 325 & $1 p+1 b f$ & 89 & 129.34 & 362 & 127 & 2 & 392 & 0.9 & 61.3 & 70.4 & 4.2 \\
\hline & $\mathrm{F}$ & 35.6 & 180 & 195 & 281 & $1 p+1 b f$ & 102 & 84.64 & 249 & 69 & 3 & 266 & 0.9 & 59.2 & 66.7 & 4.0 \\
\hline \multirow[t]{2}{*}{ Erc-1 } & D & 5.2 & 97 & 82 & 201 & $2 p$ & 54 & 103.24 & 496 & 136 & 27 & 529 & 0.8 & 36.3 & 45.9 & 2.8 \\
\hline & E & 18.5 & 157 & 139 & 232 & $1 p+1 b f$ & 82 & 334.30 & 3004 & 154 & 40 & 3041 & 0.9 & 20.4 & 23.7 & 1.4 \\
\hline \multirow[t]{3}{*}{ Lac-1 } & D & 14.9 & 120 & 129 & 290 & $2 p$ & 76 & 100.48 & 388 & 102 & 8 & 412 & 0.9 & 45.3 & 53.3 & 3.2 \\
\hline & E & 26.8 & 182 & 148 & 325 & $2 p$ & 95 & 112.17 & 477 & 142 & 6 & 511 & 0.9 & 40.8 & 46.4 & 2.8 \\
\hline & $\mathrm{F}$ & 15.6 & 146 & 112 & 291 & $2 p$ & 77 & 83.45 & 213 & 65 & 2 & 229 & 0.9 & 67.8 & 79.6 & 4.8 \\
\hline \multirow[t]{2}{*}{ Lac-2 } & E & 9.1 & 103 & 102 & 256 & $2 p$ & 64 & 51.98 & 294 & 46 & 8 & 305 & 0.8 & 31.6 & 38.5 & 2.3 \\
\hline & $\mathrm{F}$ & 7.1 & 82 & 77 & 267 & $1 p+1 b f$ & 52 & 86.58 & 397 & 111 & 9 & 423 & 0.8 & 38.0 & 48.4 & 2.9 \\
\hline \multirow[t]{3}{*}{ Foi-1 } & D & 10.8 & 104 & 104 & 284 & $2 p$ & 66 & 236.12 & 755 & 189 & 19 & 801 & 0.8 & 54.8 & 66.2 & 4.0 \\
\hline & E & 9.5 & 125 & 140 & 206 & $2 p$ & 70 & 232.14 & 2490 & 129 & 19 & 2520 & 0.8 & 17.1 & 20.4 & 1.2 \\
\hline & $\mathrm{F}$ & 21.1 & 104 & 105 & 270 & $1 p+1 b f$ & 80 & 456.64 & 2754 & 192 & 23 & 2800 & 0.9 & 30.3 & 35.3 & 2.1 \\
\hline \multirow[t]{3}{*}{ Bou-1 } & D & 7.4 & 102 & 111 & 212 & $2 p$ & 62 & 85.88 & 347 & 39 & 4 & 356 & 0.8 & 44.8 & 54.7 & 3.3 \\
\hline & E & 4.6 & 94 & 98 & 173 & $2 p$ & 54 & 39.87 & 217 & 57 & 4 & 230 & 0.8 & 32.1 & 40.6 & 2.4 \\
\hline & $\mathrm{F}$ & 6.2 & 108 & 79 & 220 & $2 p$ & 56 & 129.71 & 396 & 129 & 9 & 427 & 0.8 & 56.5 & 70.8 & 4.2 \\
\hline \multirow[t]{3}{*}{ Mas-1 } & D & 6.1 & 98 & 101 & 198 & $2 p$ & 58 & 470.10 & 3522 & 130 & 51 & 3553 & 0.8 & 24.6 & 30.4 & 1.8 \\
\hline & $E$ & 6.9 & 89 & 95 & 207 & $1 p+1 b f$ & 56 & 602.52 & 3796 & 161 & 10 & 3835 & 0.8 & 29.2 & 36.4 & 2.2 \\
\hline & $\mathrm{F}$ & 4.2 & 81 & 63 & 177 & $2 b f$ & 44 & 472.82 & 2727 & 225 & 36 & 2781 & 0.8 & 31.6 & 41.9 & 2.5 \\
\hline
\end{tabular}

${ }^{a}$ The $2 p$ geometry corresponds to grains with two pyramids, $1 p+1 b f$ means one pyramid and one broken face, and $2 b f$ means two broken faces.

to be implemented in QTQt modeling as age data only are very nonunique in terms of defining the temperature history (K. Gallagher, personal communication). Here our zircon grains are much older (Hercynian?) and hence bear much more radiation damages. As a consequence, they are better reproduced using a high damaged zircon annealing model. We have therefore considered the temperature inferred from the earliest phases of our thermal histories with caution.

Gautheron et al. [2009] focused on a linear physical trapping He retention law explaining AHe age and diffusion relationships and is calibrated with old samples and eU-rich apatite grains, whereas Flowers et al. [2009] attempted to best fit natural and partially annealed apatite grains in an empiric way. As discussed in Fillon et al. [2013] there are slight differences between predictions from AHe diffusion model of Gautheron et al. [2009] and from Flowers et al. [2009] (RDAAM). However, the RDAAM (radiation damage accumulation and annealing model) approach is better calibrated for low damaged apatite crystals. Because our apatite grains collected on granite samples are relatively young, we may expect a low amount of radiation damage. We then considered the diffusion model of Flowers et al. [2009] in our modeling approach.

The most recent kinetic model of He diffusion in zircon [Guenthner et al., 2013] has recently been implemented in QTQt. However, for some specific complications linked to acceptable fit between this model and data from this study, we have not included the ZHe ages in the inversion approach and modeled them independently using a forward approach (cf. section 5.2).

During the inversion procedure an initial model defined by a randomly chosen time-temperature path and kinetic parameters is generated, allowing the production of synthetic data, which are compared to the input data. These initial conditions are then slightly modified, and a new set of synthetic data is produced 


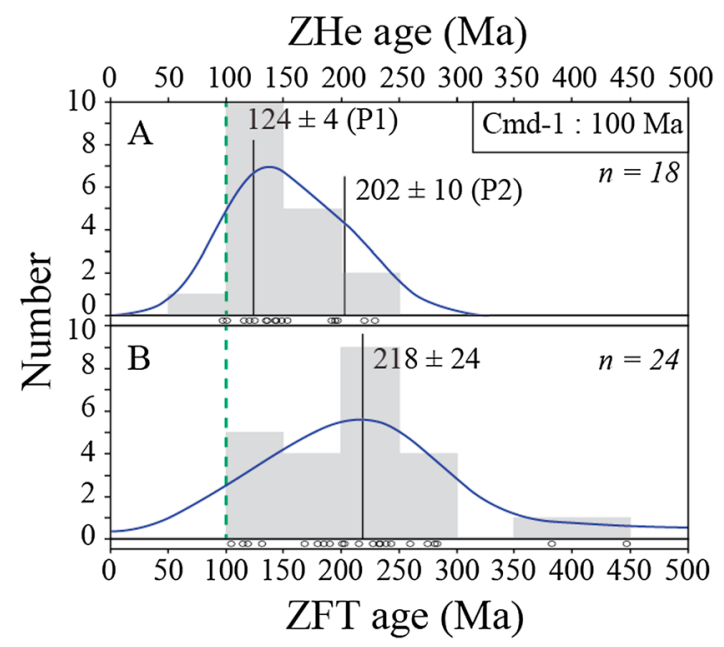

Figure 8. Detrital (a) ZHe and (b) ZFT ages from the Camarade basin (Cmd-1). Representative age components result from the deconvolution of age distributions using DensityPlotter [Vermeesch, 2009, 2012]. and compared to the input data. The model that best fits the data is retained, and the procedure is repeated until a stable solution is obtained. All the models presented in this study are based on a stable solution obtained after 1,000,000 iterations (see discussion about likelihood and posterior chains in Gallagher [2012]).

The final model is represented by a set of time-temperature histories for which a probability is calculated in the temperature-time space $\left(1^{\circ} \mathrm{C} \times 1 \mathrm{Ma}\right)$. Statistical information useful for evaluating the confidence of the fits between synthetic data produced by the model and the input data are also presented. They include the expected model (weighted mean model) and the maximum likelihood model (best data fitting model). For more details about the modeling procedure, the reader is referred to Gallagher [2012].

\subsection{Forward HeFTy Modeling of ZHe Data}

Both QTQt and HeFTy softwares have been implemented with the last model that account for concomittent evolution of damage and diffusivity as a function of time and temperature in zircon grains [Guenthner et al., 2013]. Practically, the eU measured in zircon from individual samples or for samples that experienced a similar thermal history provides a proxy for the rate of alpha production and therefore for the relative radiation damage accumulation. Data published by Guenthner et al. [2013] clearly document the dependence of diffusivity to such $\alpha$ dose experienced by the zircon crystals. Diffusivity varies for orders of magnitudes with negative and positive correlations on both sides of a maximum retentivity reached for alpha dose of $\sim 5 \times 10^{17} \mathrm{\alpha} / \mathrm{g}$ [Guenthner et al., 2013]. These data are fundamental to understand and explain the eUdates correlations of individual samples, sometimes positive, sometimes negative, documented for zircon in the literature and in this study (Figure 9). Such experimental diffusivity/ $\alpha$ dose correlations represent the cornerstone of the clever model that has now been implemented in both QTQt and HeFty softwares. However, for any time-temperature path, the final modeled ${ }^{4} \mathrm{He}$ concentration, and resulting date, will also be dependent on the ability of the model to correctly quantify the amount of radiation damage that has been preserved in the crystal.

We have performed forward modeling using HeFTy in order to check if the negative age-eU correlations observed for individual samples and cluster of samples (Figure 9) could be explained by any realistic $t-T$ paths. Because these correlations are best expressed for samples from the high and low elevation of the 35 profile, we started from the QTQt inversion output of these 3S samples (simulation 1 in Figure 9). We additionally explored two distinct sets of variation: (i) with decreasing temperature of the Mesozoic reheating phase (simulations 1 to 3 ) and (ii) with additional more pronounced Apto-Albian cooling event (simulations 4 to 6).

\section{Thermal History Modeling}

\subsection{Model Setup}

The model setup is defined by initial time-temperature constraints obtained from geological data such as $\mathrm{U} / \mathrm{Pb}$ crystallization ages determined from the granite massifs. In the Pyrenees, most of the U/Pb dated plutons have ages close to $305 \pm 5 \mathrm{Ma}$ on average [Gleizes et al., 2006; Roberts et al., 2000; Paquette et al., 1997; Maurel et al., 2004; Respaut and Lancelot, 1983; Olivier et al., 2008; Ternet et al., 2004; Vacherat, 2014; C. Guerrot, Résultats de datation U-Pb par dissolution sur zircons pour le granite de Cauterets, Pyrénées, unpublished report, SMN/PEA/ISO 146/98 CG/NB, BRGM, Orléans, 1998]. The plutons we studied were emplaced in the Carboniferous and show chemical characteristics similar to other Variscan granite in 
Table 6. Analytical Results for ZHe Analyses Performed on the Cmd-1 Detrital Sample ${ }^{a}$

\begin{tabular}{|c|c|c|c|c|c|c|c|c|c|c|c|c|c|c|c|c|}
\hline Sample & Aliquot & $\begin{array}{l}\text { Weight } \\
(\mu \mathrm{g})\end{array}$ & $\begin{array}{c}W \\
(\mu \mathrm{m})\end{array}$ & $\begin{array}{c}L \\
(\mu \mathrm{m})\end{array}$ & $\begin{array}{c}H \\
(\mu \mathrm{m})\end{array}$ & Geometry & $\begin{array}{c}\text { Rs } \\
(\mu \mathrm{m})\end{array}$ & $\begin{array}{c}{\left[{ }^{4} \mathrm{He}\right]} \\
(\mathrm{nmol} / \mathrm{g})\end{array}$ & $\begin{array}{c}{[\mathrm{U}]} \\
(\mathrm{ppm})\end{array}$ & $\begin{array}{l}{[\mathrm{Th}]} \\
(\mathrm{ppm})\end{array}$ & $\begin{array}{l}{[\mathrm{Sm}]} \\
(\mathrm{ppm})\end{array}$ & $\begin{array}{c}\mathrm{eU} \\
(\mathrm{ppm})\end{array}$ & $F_{T}$ & $\begin{array}{c}\text { Measured } \\
\text { Age }(\mathrm{Ma})\end{array}$ & $\begin{array}{l}\text { Corrected } \\
\text { Age (Ma) }\end{array}$ & $\begin{array}{l}\text { Error } \\
(1 \sigma)\end{array}$ \\
\hline \multirow[t]{35}{*}{ Cmd-1 } & 1 & 5.0 & 110 & 90 & 179 & $1 p+1 b f$ & 57 & 114.07 & 66 & 71 & 5 & 83 & 0.9 & 255.0 & 300.1 & 18.0 \\
\hline & 2 & 3.0 & 77 & 57 & 180 & $2 p$ & 42 & 162.63 & 194 & 50 & 0 & 206 & 0.8 & 146.9 & 183.9 & 11.0 \\
\hline & 3 & 3.0 & 94 & 74 & 189 & $1 p+1 b f$ & 51 & 125.52 & 250 & 112 & 5 & 277 & 0.8 & 84.3 & 101.1 & 6.1 \\
\hline & 5 & 1.0 & 67 & 47 & 214 & $2 p$ & 37 & 527.95 & 1146 & 639 & 15 & 1299 & 0.8 & 75.5 & 97.0 & 5.8 \\
\hline & 7 & 3.0 & 84 & 64 & 162 & $2 p$ & 44 & 150.73 & 186 & 60 & 8 & 200 & 0.8 & 139.9 & 173.9 & 10.4 \\
\hline & 8 & 1.0 & 81 & 61 & 144 & $1 p+1 b f$ & 41 & 304.23 & 376 & 98 & 10 & 399 & 0.8 & 141.6 & 177.9 & 10.7 \\
\hline & 9 & 1.0 & 82 & 62 & 160 & $2 p$ & 43 & 224.51 & 636 & 326 & 15 & 714 & 0.8 & 58.5 & 73.2 & 4.4 \\
\hline & 11 & 4.0 & 89 & 69 & 219 & $2 p$ & 50 & 230.15 & 390 & 93 & 16 & 412 & 0.8 & 103.8 & 124.7 & 7.5 \\
\hline & 13 & 2.0 & 95 & 75 & 168 & $1 p+1 b f$ & 50 & 435.41 & 416 & 342 & 29 & 498 & 0.8 & 162.6 & 196.7 & 11.8 \\
\hline & 15 & 2.0 & 88 & 68 & 193 & $1 p+1 b f$ & 48 & 189.11 & 207 & 116 & 19 & 235 & 0.8 & 149.8 & 181.7 & 10.9 \\
\hline & 16 & 5.0 & 86 & 66 & 185 & $1 p+1 b f$ & 48 & 201.79 & 308 & 120 & 16 & 337 & 0.8 & 111.3 & 134.9 & 8.1 \\
\hline & 17 & 3.0 & 93 & 73 & 201 & $2 p$ & 50 & 170.87 & 278 & 112 & 21 & 305 & 0.8 & 104.3 & 125.2 & 7.5 \\
\hline & 18 & 58.0 & 96 & 76 & 229 & $1 p+1 b f$ & 54 & 8.42 & 14 & 5 & 1 & 15 & 0.9 & 101.8 & 120.3 & 7.2 \\
\hline & 19 & 24.0 & 102 & 82 & 161 & $1 p+1 b f$ & 52 & 43.95 & 62 & 26 & 1 & 68 & 0.8 & 119.7 & 142.9 & 8.6 \\
\hline & 20 & 19.0 & 96 & 76 & 168 & $2 p$ & 49 & 9.68 & 16 & 22 & 2 & 22 & 0.8 & 83.4 & 101.7 & 6.1 \\
\hline & 21 & 16.0 & 80 & 60 & 201 & $2 p$ & 44 & 53.27 & 74 & 35 & 3 & 83 & 0.8 & 119.9 & 148.2 & 8.9 \\
\hline & 22 & 17.0 & 67 & 47 & 179 & $2 p$ & 36 & 19.14 & 28 & 12 & 0 & 31 & 0.8 & 114.4 & 148.8 & 8.9 \\
\hline & 26 & 13.0 & 77 & 57 & 144 & $1 p+1 b f$ & 40 & 36.52 & 31 & 19 & 7 & 36 & 0.8 & 189.5 & 241.0 & 14.5 \\
\hline & 27 & 7.0 & 82 & 62 & 180 & $2 p$ & 44 & 65.52 & 22 & 92 & 1 & 44 & 0.8 & 276.0 & 348.7 & 20.9 \\
\hline & 28 & 13.0 & 73 & 53 & 143 & $1 p+1 b f$ & 38 & 69.38 & 59 & 56 & 0 & 72 & 0.8 & 178.2 & 230.8 & 13.8 \\
\hline & 29 & 8.0 & 93 & 73 & 181 & $2 p$ & 49 & 27.11 & 20 & 42 & 5 & 30 & 0.8 & 169.2 & 206.8 & 12.4 \\
\hline & 31 & 17.0 & 76 & 56 & 146 & $2 p$ & 39 & 22.17 & 4 & 12 & 2 & 6 & 0.8 & 636.4 & 832.5 & 49.9 \\
\hline & 32 & 8.0 & 107 & 87 & 180 & $2 p$ & 55 & 70.10 & 57 & 52 & 5 & 69 & 0.8 & 187.6 & 223.3 & 13.4 \\
\hline & 34 & 4.0 & 90 & 70 & 181 & $2 p$ & 48 & 489.29 & 725 & 171 & 8 & 766 & 0.8 & 118.7 & 144.3 & 8.7 \\
\hline & 35 & 2.0 & 64 & 44 & 240 & $1 p+1 b f$ & 35 & 406.55 & 217 & 136 & 23 & 250 & 0.8 & 302.4 & 392.4 & 23.5 \\
\hline & 36 & 4.0 & 87 & 67 & 202 & $2 p$ & 48 & 266.80 & 367 & 106 & 1 & 392 & 0.8 & 126.3 & 153.4 & 9.2 \\
\hline & 38 & 2.0 & 81 & 61 & 192 & $2 p$ & 44 & 280.94 & 309 & 161 & 0 & 348 & 0.8 & 150.1 & 185.8 & 11.2 \\
\hline & 41 & 25.0 & 164 & 144 & 306 & $1 p+1 b f$ & 91 & 260.25 & 229 & 211 & 6 & 280 & 0.9 & 173.2 & 188.8 & 11.3 \\
\hline & 44 & 3.0 & 69 & 49 & 216 & $2 p$ & 38 & 265.96 & 299 & 108 & 10 & 325 & 0.8 & 152.3 & 193.7 & 11.6 \\
\hline & 51 & 5.0 & 81 & 61 & 219 & $2 p$ & 45 & 115.90 & 209 & 80 & 12 & 228 & 0.8 & 94.5 & 115.8 & 6.9 \\
\hline & 55 & 4.0 & 77 & 57 & 189 & $1 p+1 b f$ & 42 & 124.00 & 26 & 79 & 4 & 45 & 0.8 & 517.8 & 657.2 & 39.4 \\
\hline & 56 & 5.0 & 96 & 76 & 188 & $1 p+1 b f$ & 51 & 295.73 & 269 & 126 & 7 & 299 & 0.8 & 183.7 & 219.6 & 13.2 \\
\hline & 57 & 3.0 & 64 & 44 & 170 & $1 p+1 b f$ & 34 & 239.67 & 149 & 53 & 6 & 162 & 0.8 & 275.7 & 362.6 & 21.8 \\
\hline & 58 & 5.0 & 76 & 56 & 228 & $2 p$ & 42 & 164.81 & 172 & 93 & 5 & 195 & 0.8 & 157.3 & 195.7 & 11.7 \\
\hline & 63 & 2.0 & 93 & 73 & 201 & $2 p$ & 51 & 366.24 & 572 & 131 & 3 & 603 & 0.8 & 112.8 & 135.2 & 8.1 \\
\hline
\end{tabular}

\footnotetext{
${ }^{a}$ The $2 p$ geometry corresponds to grains with two pyramids, $1 p+1 b f$ means one pyramid and one broken face, and $2 \mathrm{bf}$ means two broken faces. Data in italics
} correspond to grains with $\mathrm{He}$ and/or $\mathrm{U}$ and Th contents that are lower than the limit of quantitation.

the Pyrenees [Michard-Vitrac et al., 1980; Wickham and Taylor, 1985; Bickle et al., 1988]. We infer that they recorded melting from the same protolith and crystallized at the same depth. This implies that these plutons also cooled at $305 \pm 5 \mathrm{Ma}$ from temperatures of $900 \pm 50^{\circ} \mathrm{C}$, according to the $\mathrm{U} / \mathrm{Pb}$ closure temperature in zircon [Lee et al., 1997; Cherniak and Watson, 2000].

According to geological maps, Triassic successions lying on top of the Arize and 3S massifs are located at a distance of less than $3 \mathrm{~km}$ from our granitic samples. We therefore assume that at the time of deposition of Triassic sandstones and evaporites, granites of the Arize and 35 Paleozoic massifs were buried at less than $3 \mathrm{~km}$ depth. These massifs thus recorded near-surface conditions $<100^{\circ} \mathrm{C}\left(50 \pm 50^{\circ} \mathrm{C}\right)$ during the Triassic $(225 \pm 25 \mathrm{Ma})$. We note this early unroofing event, which was also associated with a widespread magmatic (ophitic) event [Rossi et al., 2003], is well recognized both in the north and the south of the Pyrenees in the Albian sediments [Filleaudeau et al., 2011; Vacherat et al., 2014]. These data probably outline initiation of the rifting processes in the Pyrenean region and predates the Atlantic Ocean opening [Marzoli et al., 1999; Olsen, 1997].

Because the exact original position of our rock samples within each sampled granite is unknown, we assume that samples are organized vertically in a column of rocks with their position defined by their current elevation. This assumption is tested and discussed in the following. Because the thermal structure of the area is not constrained in the region, the vertical geothermal gradient is a free parameter that is adjusted with time during the model run. 

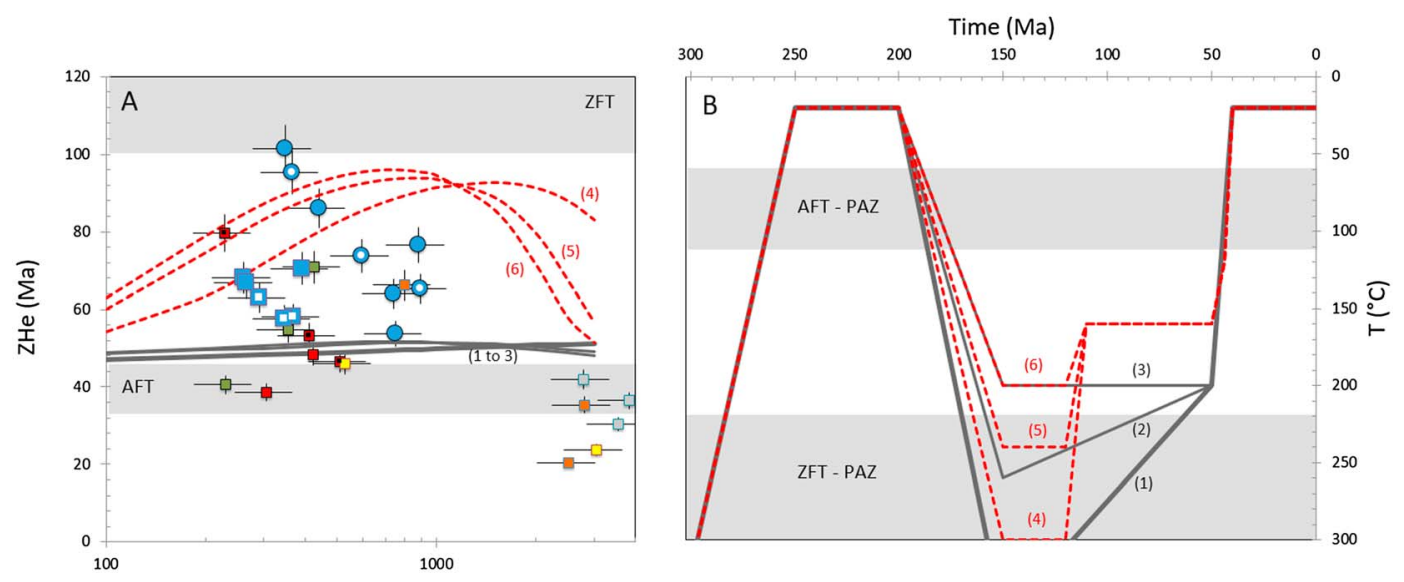

Figure 9. (a) ZHe date-eU correlations with same color code as for Figure 6. Individual samples correlations are highlighted for three of them to show the existence of negative trends (see full individual date-eU plots in Figure S1). Most of the data plot along two main clusters of negative trends best supported by the upper (blue circles) and lower $3 \mathrm{~S}$ (blue squares) profile samples. Lines labeled from 1 to 6 have been forward modeled using HeFTy software [Ketcham, 2005] using (b) the $t-T$ paths. Simulation 1 corresponds to the output of the QTQt inversion for the 35 profile (Figure 12). Some additional variations have been tested with decreasing temperature of the Mesozoic reheating phase (simulations 2 and 3) and additional more pronounced Apto-Albian cooling event (simulations 4-6). See section 6.3 for more details concerning the interpretation and the apparent inability of the model to fit the data.

Figures 2, 6a, and 10 show that our ZFT ages are separated into two groups. The first group is represented by the samples with the youngest ZFT central ages in the 90-110 Ma range (Bou-1, 3S-2 to 3S-5). They are positioned to the south of the Arize or 3S massifs, at $981 \mathrm{~m}$ (Bou-1) and from 2068 to $1700 \mathrm{~m}$ (3S-2 to 3S-5), respectively. The second group comprises the oldest samples (Foi-1, Lac-1, Lac-2, and Erc-1) with ZFT ages between $\sim 135 \mathrm{Ma}$ and $\sim 170 \mathrm{Ma}$ that are located to the north of the massifs and at lower elevation of $\sim 500 \mathrm{~m}$. The highest sample (3S-1) obtained in the 35 massif yields a ZFT age of $\sim 153 \mathrm{Ma}$ is considered at the boundary between the two domains defined above (Figure 10).

The correlation observed between the ZFT dates and their location may reflect a differential cooling history between the two flanks of the Arize and 35 massifs. Because all ZFT ages are preorogenic, the age distribution may reflect partial resetting or cooling associated with rifting processes.

To test this, we treated the groups of samples separately according to their location (Figure 10). We define four domains characterized by independent time-temperature histories. The thermal history of the southern flank of the $3 S$ massif is modeled using the $3 S$ profile (3S-1 to 3S-7), while on the northern flank it is constrained by the Erc-1 sample. As shown in Figures 1 and 3, the Ercé pluton (Erc-1) lies in contact with the Cenomanian to Coniacian deposits "Flyschs à Fucoïdes." We therefore define an additional timetemperature constraint at $90 \pm 10 \mathrm{Ma}$ and $50 \pm 50^{\circ} \mathrm{C}$ for this domain only. Time-temperature models of the

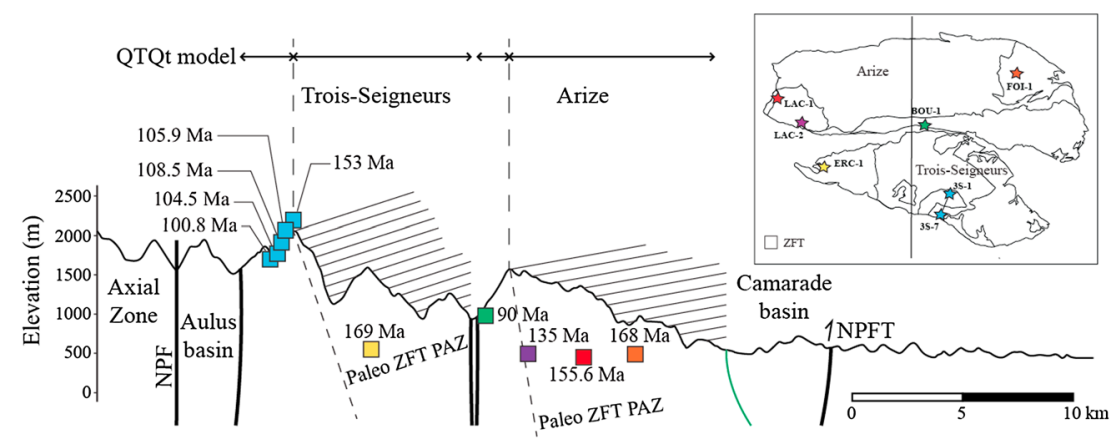

Figure 10. Elevations, ZFT ages, and positions of the samples projected on a simplified N-S cross section through the Ariège area. Our results suggest that a north dipping paleo-PAZ for ZFT (dashed lines) is present both in the Arize and Trois-Seigneurs massifs. 

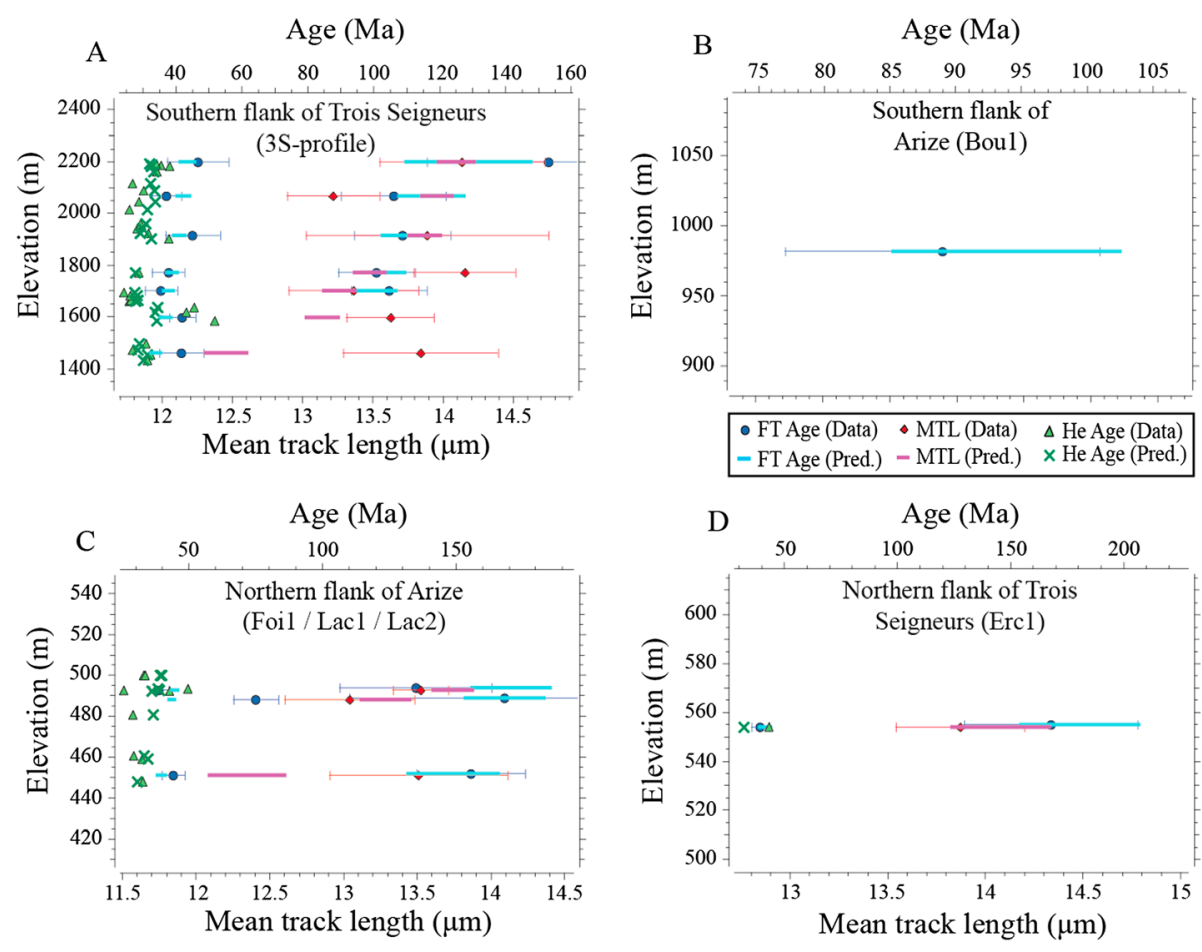

Figure 11. Summary of the AHe, AFT, and ZFT data predictions from QTQt inversion model. These data are compared to the AHe, AFT, and ZFT data measured on our granite samples in the southern flank of (a) the $3 \mathrm{~S}$ and (b) the Arize massifs and in the northern flank of (c) Arize and (d) the 35 massifs.

Arize massif are defined by Bou-1 on its southern flank, whereas Lac-1, Lac-2, and Foi-1 samples are used for the northern flank. The inverse modeling of these four regions account for all AFT data (counted and measured tracks, average Dpar), ZFT, and AHe data with the model setup described above.

\subsection{QTQt Modeling Results}

Figure 11 shows model results with the fit of the data for individual thermochronometers and for the four regions $(A, B, C$, and $D)$. We see that the predicted and measured $A H e$ ages are well correlated within error in all the massifs. Our AFT ages are also well reproduced with the noticeable exception of the Foi- 1 sample for which a younger age of $\sim 40 \mathrm{Ma}$ is predicted. AFT mean track lengths are also well fitted except for the lower elevation samples, for which the predicted MTL ( 12 to $\sim 13 \mu \mathrm{m})$ are shorter than the measured track lengths. This model allows fitting all ZFT ages within error (Figure 11).

Figure 12 presents the time-temperature histories corresponding to data fitting shown in Figure 11. They show an initial cooling phase between $\sim 300 \mathrm{Ma}$ and $\sim 200 \mathrm{Ma}$ shared by all the studied domains. However, other constraints from higher temperature thermochronometers would be needed to explore in details the exact cooling patterns between 300 and 200 Ma.

Following this cooling phase, modeling predicts that the southern flank of the $3 \mathrm{~S}$ massif experienced heating to temperatures of $\sim 375-325^{\circ} \mathrm{C}$ between $\sim 140$ and $\sim 130 \mathrm{Ma}\left(\sim 3.3^{\circ} \mathrm{C} / \mathrm{Myr}\right.$; Figure 12a). It is followed by cooling from $\sim 130 \mathrm{Ma}$ to $\sim 50 \mathrm{Ma}$ at a slow rate of $\sim 1.9^{\circ} \mathrm{C} / \mathrm{Myr}$. From 50 to $33 \mathrm{Ma}$ cooling accelerates and reaches a rate of $\sim 12^{\circ} \mathrm{C} / \mathrm{Myr}$. Since $33 \mathrm{Ma}$, samples recorded near-surface temperature conditions. Samples on the southern flank of the Arize massif inversion model (Figure 12b) also recorded heating after $\sim 200 \mathrm{Ma}$, reaching temperatures between $\sim 425^{\circ} \mathrm{C}$ and $\sim 375^{\circ} \mathrm{C}$ at $115-105 \mathrm{Ma}$ corresponding to a heating rate of $\sim 3^{\circ} \mathrm{C} / \mathrm{Myr}$. The lack of AFT, ZHe, and AHe constraints did not allow to define an accurate cooling history. An apparent linear cooling phase is assumed after 115-105 Ma, reaching surface conditions at present. The cooling rate and history in the Cenozoic is unconstrained in this part of the massif.

Samples from the northern flank of the Arize massif (Figure 12c) show a longer heating phase from $\sim 200 \mathrm{Ma}$ to $\sim 50 \mathrm{Ma}$, reaching temperatures of $\sim 300^{\circ} \mathrm{C}$ to $\sim 350^{\circ} \mathrm{C}$ at a heating rate of $2^{\circ} \mathrm{C} / \mathrm{Myr}$. In about 

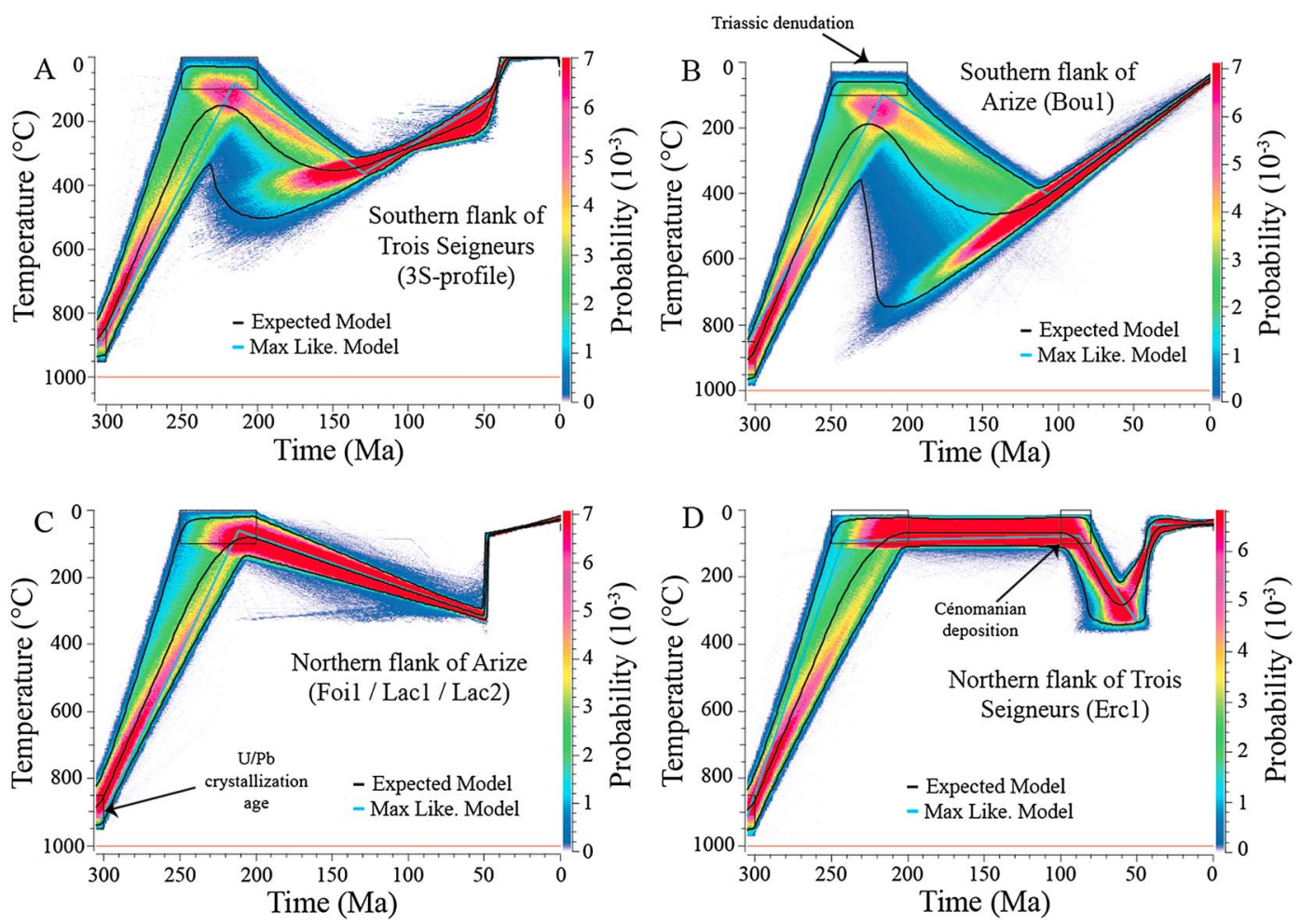

Figure 12. Time-temperature histories inferred from QTQt inversion of AHe, AFT, and ZFT of our granite samples in the southern flank of (a) the $3 \mathrm{~S}$ and (b) the Arize massifs and in the northern flank of (c) the Arize and (d) the 35 massifs.

$5 \mathrm{Myr}$, from $\sim 50$ to $45 \mathrm{Ma}$ temperature decreased to $\sim 75^{\circ} \mathrm{C}$ consistent with an extreme cooling rate of $\sim 50^{\circ} \mathrm{C} / \mathrm{Myr}$. From this fast cooling period on, the northern Arize massif recorded cooling to surface conditions at a slow rate of $\sim 1.7^{\circ} \mathrm{C} / \mathrm{Myr}$.

Modeling of the northern flank of the 35 massif (Figure 12d) shows that after $90 \mathrm{Ma}$, the massif recorded heating to temperatures of $\sim 250^{\circ} \mathrm{C}$ to $\sim 350^{\circ} \mathrm{C}$ reached between $\sim 70$ and $\sim 50 \mathrm{Ma}\left(\sim 8.3^{\circ} \mathrm{C} / \mathrm{Myr}\right)$. This was followed by a rapid cooling episode until $\sim 35 \mathrm{Ma}$ at a rate of $\sim 17^{\circ} \mathrm{C} / \mathrm{Myr}$.

\subsection{HeFTy Modeling Results of ZHe Data}

To complement the thermal histories deduced from the QTQt inversions and described above, we performed forward modeling of ZHe data with HeFTy (see section 5.2). Our goal was to (i) enrich previous inversion modeling in the range of temperature for which thermochronometers were lacking (i.e. $\sim 200-120^{\circ} \mathrm{C}$ ) and (ii) test if the recent model proposed by Guenthner et al. [2013], which partially cover this temperature range, can explain the date-eU correlations observed for these samples (Figure 9).

As illustrated on Figure 9a, one can observe that all simulated $t-T$ paths from 1 to 3 exhibit near-flat date-eU relationships with ages centered at about $50 \mathrm{Ma}$ due to rapid cooling from $\sim 200^{\circ} \mathrm{C}$ at that time. Results of simulations 4 to 6 indicate that it is necessary to envisage a more pronounced Apto-Albian cooling to preserve Mesozoic ages in the ZHe record. According to the new damage-dependent model implemented in HeFTy [Guenthner et al., 2013], it is necessary to cool down samples as low as $160^{\circ} \mathrm{C}$ to significantly preserve old Mesozoic ages for eU ranging from 100 to $2000 \mathrm{ppm}$, whereas samples with higher eU concentrations will record younger ages due to their high amount of accumulated damages and consequently lower retention of helium.

For simulations 4 to 6 , the shape of the date-eU relationships is characterized by a first positive correlation, a maximum, and a subsequent negative correlation (Figure 9). This typical shape is related to the diffusion parameters $-\alpha$ dose correlation used for calibration of the model. Even if the simulations 4 to 6 qualitatively exhibit negative date-eU correlations, it has not been possible to shift them significantly toward lower eU and allow acceptable fit with the data. The theoretical position of the maximum between positive and negative correlations is anchored by the model at $\sim 5 \times 10^{17} \alpha / g$. This value is modulated by the eU/age ratio and 
the amount of subsequent annealing. We can observe in Figure 9 that the position of the maximum is displaced toward the lower eU when the temperature reached during heating is decreasing, and therefore when the amount of annealed damages is decreasing: the higher amount of damages is annealed during reheating, the higher concentration of eU is necessary to reach the $\alpha$ dose corresponding to the maximum of retention. For the case of these Pyrenean granites ( 305 Ma old), if one takes into account the total $\alpha$ dose received by the zircon grains and consider that almost all these radiation damages have been preserved and never annealed, the lowest possible eU for the position of the maximum retention will be $\sim 500 \mathrm{ppm}$.

Although the modeling we have carried out suggests that the range of ZHe ages and the existence of negative correlations can be qualitatively reproduced by the damage-dependent model of diffusion [Guenthner et al., 2013], quantitatively, they question and challenge it because (i) the maximum retention seems to be for them effectively at very low eU (200-300 ppm) and (ii) the model is unable to simulate it at such concentrations. This apparent unability of the model to correctly simulate the date-eU correlations is a strong limitation for modeling data from this study and do not allow us to invert them with other thermochronological data in QTQt. This aspect concerning the calibration of damage-dependent models for helium diffusion in zircon will certainly merit new experimental data and modeling approaches in the future. Indeed, the range of closure temperatures covered by this system is actualy complementary to ZFT and AFT data and would certainly allow more precise inversions of this critical thermochronological window (200 to $120^{\circ} \mathrm{C}$ ).

\section{Discussion}

\subsection{Variability in Low-Temperature Thermochronogical Dates}

AFT analyses in the Arize and $3 \mathrm{~S}$ massifs show a relatively narrow range of ages from $35.4 \mathrm{Ma}$ to $46.5 \mathrm{Ma}$ (Figure $6 a$ and Tables 2 and S2). This result is consistent with previous AFT ages found in the region [Yelland, 1991; Morris et al., 1998; Fitzgerald et al., 1999; Sinclair et al., 2005], with a noticeable exception of the Foix granite that yields an age of $74.9 \pm 1.2 \mathrm{Ma}$. This age is significantly younger than the one obtained by Yelland [1991] at $106.3 \pm 5.3 \mathrm{Ma}$ at a similar elevation (Table 1). Measured mean track lengths (Figure 7 and Tables 2 and S2) are also consistent with already published data as they range from $13.0 \mu \mathrm{m}$ to $14.5 \mu \mathrm{m}$ [Fitzgerald et al., 1999; Morris et al., 1998; Yelland, 1990].

The QTQt models indicate that all AFT and AHe data are consistent with a cooling phase starting at $\sim 50 \mathrm{Ma}$ and lasting until $\sim 35 \mathrm{Ma}$ (Figures 12a, 12b, and 12d). However, predicted MTL for the lowermost elevation samples are shorter than the measured apatite MTL (Figures 11a and 11c). This probably reflects that our samples are positioned in a synthetic vertical column of rocks according to their relative altitude. Consequently, samples that resided deep enough and for a sufficient period of time (here since $\sim 35 \mathrm{Ma}$ ) will record sufficiently high temperatures to have their track lengths reduced in the QTQt modeling. Because all measured apatite MTL are similar in our samples, we suggest all these rocks resided near-surface conditions since the last cooling phase started.

ZFT analyses yielded two groups of ages, from $\sim 135 \mathrm{Ma}$ and $\sim 169 \mathrm{Ma}$ and from 90 Ma to $109 \mathrm{Ma}$ (Figure 6a and Table 3). Yelland [1991] obtained an age of 71.4 \pm 3.1 Ma on the Lacourt pluton, which is younger than our measured age of $135.0 \pm 14.0 \mathrm{Ma}$ (Lac-2) on the same massif at a similar location. He also found an age of 79.7 $\pm 5.4 \mathrm{Ma}$ on the Arize migmatite that is slightly younger than our ZFT date on the same massif $90.0 \pm 5.9 \mathrm{Ma}$ (Bou-1), located $\sim 15 \mathrm{~km}$ to the west.

The lower part of the 3S-profile show a steep slope consistent with rapid cooling at 110 Ma (Figure 6a). The uppermost 3S-1 sample (153 Ma at $2199 \mathrm{~m}$ ) is older and defines an upper domain with a very slow apparent exhumation rate of $2.7 \times 10^{-3} \mathrm{~km} / \mathrm{Myr}$ and may represent the base of a Mesozoic Partial Annealing Zone (PAZ). We further notice that our old ZFT ages group of samples show a younging trend toward the south from $\sim 169 \mathrm{Ma}$ (Erc-1) to $\sim 153 \mathrm{Ma}$ (3S-1) on the 3S massif, and from 168 Ma (Foi-1) to $135 \mathrm{Ma}$ (Lac-2) on the Arize massif. Due to the northward dip of the structural grain, moving north is equivalent to move upwards into the structural section within the partially annealed zone. This suggests the occurrence of two north dipping paleo-PAZ present both in the Arize and 35 massifs (Figure 10). However, more data are needed to develop on this specific aspect of the exhumation pattern in the NPZ.

The ZHe ages measured in this study are globally distributed between values of ZFT ( 110 Ma) and AFT $(\sim 40 \mathrm{Ma})$ data. Such age variations are closely related to eU concentrations along negative correlations and 
are observed at the scale of individual samples (Figure S1) or at the scale of two main intersamples clusters (Figure 9). This is particularly spectacular for the upper and lower parts of the 3S profile, which exhibit parallel negative trends. Qualitatively, such clear age variations can certainly be related to damage-dependent sensitivity to thermal processes as recently proposed by Guenthner et al. [2013]. Unfortunately, it has not been possible to quantitatively model them correctly using HeFTy and its parametrisation. This will not allow full and precise use of the ZHe thermochronological record in the following geodynamic interpretation. Whatever the current limitations of the modeling approach of such damage-dependent multithermochronometry of ZHe, it nevertheless completes the QTQt inversions in the range between ZFT and AFT data. Indeed, the preservation of Mesozoic ages in the ZHe record implies that the rift-related Apto-Albian denudation phase has brought to shallower depth $\left(\sim 160^{\circ} \mathrm{C}\right)$ the studied samples than it is suggested by the QTQt inversion output.

\subsection{Record of Transition From Atlantic-Tethyan Rifting to Pyrenean Collision} 7.2.1. Transition From Variscan Orogeny to Onset of Tethyan-Atlantic Rifting in the Pyrenees Following the emplacement of Variscan granitic intrusions in the European basement of Northern Pyrenees at $\sim 300 \mathrm{Ma}$, the studied massifs (3S and Arize) experienced cooling in the Late Paleozoic-Triassic. Their exhumation to the surface is attested by the deposition of Late Triassic evaporites very close to the eroded granites (e.g., less than $3 \mathrm{~km}$ in the study area and directly overlying several other granites in the Pyrenees). This event is likely to be related to the initiation of post-Variscan extension of the Paleozoic crust [Vissers, 1992], as attested by the widespread occurrence of Permian magmatism and sedimentary basins [Briqueu and Innocent, 1993; Cassinis et al., 2000; Lago et al., 2004; Denèle et al., 2011]. This event is perhaps the early sign of the opening of the western Tethyan Ocean and later the Atlantic Ocean.

ZFT and ZHe age populations (202-218 Ma) recovered from the Albian sediments of the Camarade basin (Figure 8) indicate that cooling occurred in the Late Triassic-Early Jurassic. This finding is consistent with ZHe peak age of $236 \mathrm{Ma}$ found in the Albian sediments from the Mauléon basin [Vacherat et al., 2014]. This event is also well documented from ZHe and ZFT analyses in the detrital zircon grains from the southern Pyrenees [Filleaudeau et al., 2011; Whitchurch et al., 2011]. The Late Triassic to Early Jurassic period corresponds to a regional-scale exhumational event. This is documented eastward along the European margins in the Alpine realm [Manatschal, 2004] and in the Corsica-Sardinia, although slightly younger [Malusa et al., 2015]. This exhumational event was associated with widespread magmatism both in the Central Atlantic Magmatic Province, predating the opening of the Central Atlantic Ocean [Marzoli et al., 1999; Rossi et al., 2003], and in the Alpine domain associated with onset of Ligurian Tethyan rifting. This supports geodynamic models in which rifting and thermal evolution between the Alpine Tethys and the Central Atlantic oceans affected this part of Western Europe during the Late Triassic-Early Jurassic before the Iberia plate invidualized in the Jurassic to Albian times.

\subsubsection{Early Cretaceous Crustal Thinning in the Pyrenees}

Thermal models reveal that cooling in the Late Triassic-Early Jurassic period was followed by a relatively slow heating from $\sim 200$ to $\sim 130$ Ma (e.g., southern flank of Trois-Seigneurs in Figure 12a). We suggest that this episode was related to slow burial by sediments during postrift evolution of the European margin, after the late Paleozoic-Early Mesozoic rifting episode. The persistence of a carbonate platform until the Barremian and the occurrence of subaerial bauxitic deposits before the Aptian in our studied region (Figure 4) indicate that at $\sim 130 \mathrm{Ma}$, the European surface remained at a relatively high elevation. We must assume that the European lithosphere was only moderately thinned during the Paleozoic-Mesozoic extension to be kept in near-isostatic equilibrium. Alternatively, we may consider that the surface was dynamically supported by flow in a hot upper mantle. Choosing between these two hypotheses will require careful determination of basin subsidence evolution and reconstruction of past flow in the upper mantle.

Renewed cooling event is documented after $\sim 130 \mathrm{Ma}$. Differential cooling histories between the northern and southern flanks of the studied massifs point to localized subsidence and exhumation controlled by south dipping normal faults. For instance, cooling of the southern $3 \mathrm{~S}$ pictures denudation in the footwall of south dipping normal faults while the Aulus basin (hyperthinned domain) positioned in the hangingwall was subsiding (Figures 13a and 13b). The northern flank of the $3 \mathrm{~S}$ massif did not record cooling. This indicates that this part of the block was located far enough from the main fault (Figures 12d, 13a, and 13b). After $\sim 90 \mathrm{Ma}$, this part of $3 \mathrm{~S}$ block recorded subsidence and deposition of Cenomanian-Coniacian sediments (Flyschs à Fucoïdes Formation) in the Oust-Massat basin (Figure 13c). We note that deposition may be entirely due to subsidence in the downthrown block of the northern flank of the 35 massif. Alternatively, a larger-scale 

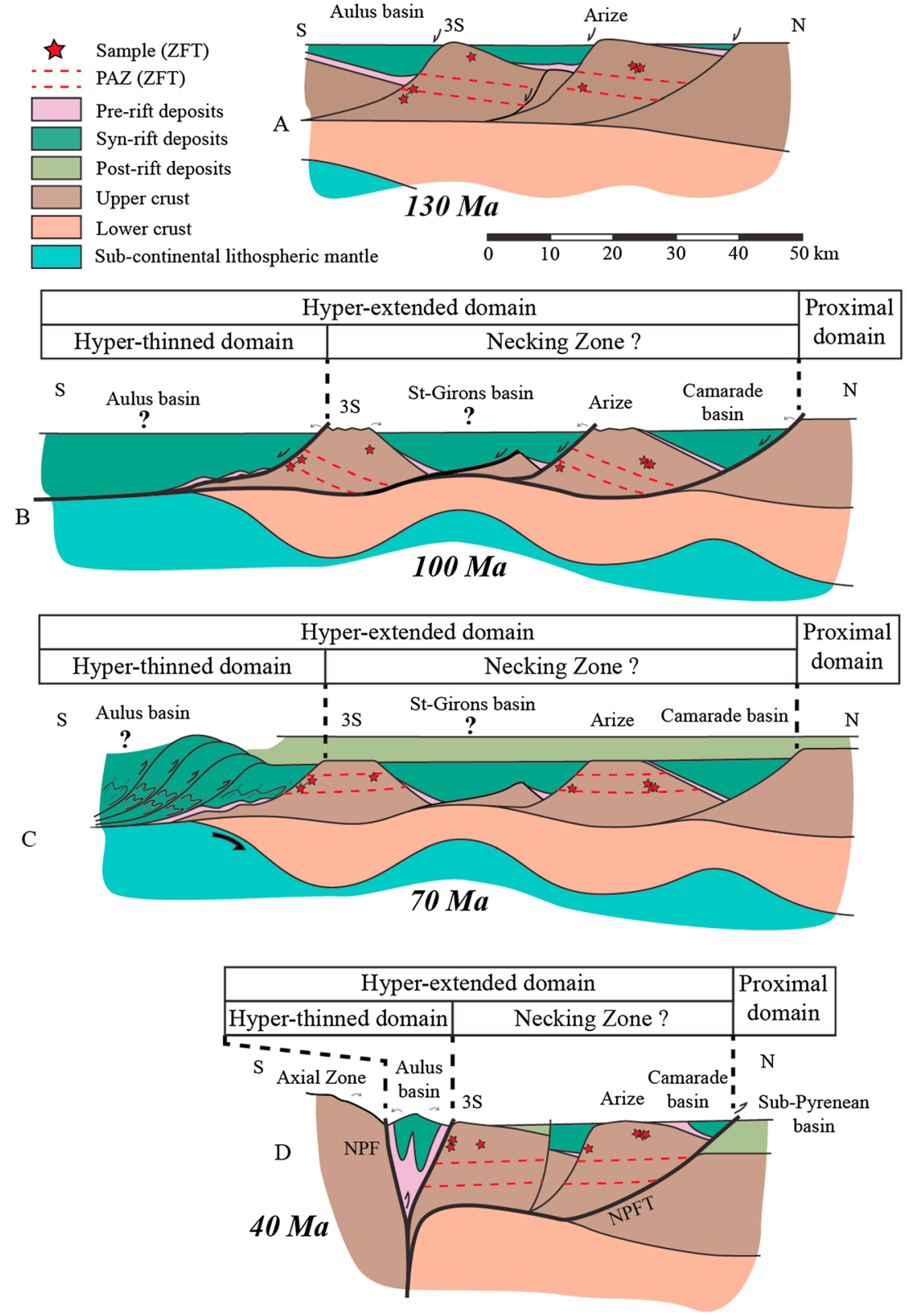

Figure 13. Schematic reconstruction of the tectonic evolution of the Ariège area based on the time-temperature histories deduced from this study. (a) At $130 \mathrm{Ma}$, rift-related extension results in south dipping normal faulting and the individualization of tilted blocks. (b) At $100 \mathrm{Ma}$, the European rifted margin architecture is divided in an extremely thinned domain, below the Aulus basin; less thinned domains (necking zone?), as represented by the $3 \mathrm{~S}$ and Arize massif and their respective cover; and the proximal European domain. The southern flanks of the massifs recorded tectonic denudation and cooling, whereas the northern flanks recorded sedimentary filling, burial, and heating. (c) At $70 \mathrm{Ma}$, convergence is accommodated by thrusting in the distal domain (the Aulus basin), resulting in the formation of a proto-Pyrenean accretionary prism. (d) At $40 \mathrm{Ma}$, the remnants of the most thinned domain (Aulus basin) that are not subducted beneath the European lithosphere are fully accreted into the subaerial orogenic prism and may record erosion. The less thinned domain (north of the Aulus basin) is also accreted into the subaerial orogenic prism.

thermally or tectonically (contractional?) controlled phase may equally be at the origin of the subsidence. This may be linked with the development of a regional-scale flysch trough during Cenomanian-Turonian times as suggested by Debroas [1990]. However, this part of the basin geohistory was not modeled in our study.

The southern flank of the Arize massif recorded a similar heating episode from 200 Ma related to subsidence and burial (Figure 12b). Onset of cooling at $\sim 110 \mathrm{Ma}$ indicates tectonic denudation in the footwall of a south 
dipping fault located south of the Arize massif (Figures 13a and 13b). Cooling appears to be delayed by about 20 Myr with respect to 35 massifs, which could be related to northward propagation of extension in the NPZ or thermal response to differential thinning. The basement of the northern flank of the Arize massif remained subsident and recorded heating from $\sim 200 \mathrm{Ma}$ to $\sim 50 \mathrm{Ma}$ (Figure 12c). This illustrates the continuous post$200 \mathrm{Ma}$ burial phase, followed by tectonically controlled northward tilting of the massif during rifting at $110 \mathrm{Ma}$ (Albo-Cenomanian sediments of the Camarade basin) (Figures 13a and 13b) and post-110 Ma burial caused by thermal relaxation (Figure 13c). The presence of Paleozoic clasts in the Albian-Cenomanian breccias and the thick $(\sim 4 \mathrm{~km})$ flysch succession of the Camarade basin suggest that subsidence was controlled by an extensional fault. Because the Camarade basin (i) is positionned in the hangingwall of the south dipping North Pyrenean Frontal Thrust (NPFT) and (ii) contained detrital ZHe P1 grain age population at 124 Ma that possibly reflects tectonic denudation in the footwall of the future NPFT, we infer that this fault was originally a south dipping detachment accommodating subsidence during the Albian-Cenomanian, delimiting the proximal European domain from a southward thinned domain. This provides a potential northern limit for the necking zone of the European margin.

\subsubsection{Onset of Exhumation in the Northern Pyrenees Controlled by Margin Architecture}

All our models confirm that the Arize and 35 massifs experienced rapid cooling between 50-48 Ma and $33 \mathrm{Ma}$. This result is generally in agreement with an onset of rapid cooling that was previously roughly defined at 50-40 Ma [Fitzgerald et al., 1999; Sinclair et al., 2005]. Modeling and new AHe data shown in this study reveal that this cooling event was more rapid and regionally distributed than originally thought. We demonstrate that cooling rates integrated between 50 and $35-33 \mathrm{Ma}$ are ranging between 12 and $15^{\circ} \mathrm{C} / \mathrm{Myr}$ and have potentially reached $50^{\circ} \mathrm{C} / \mathrm{Myr}$ between 48 and $45 \mathrm{Ma}$. Assuming a transient geothermal gradient of $30^{\circ} \mathrm{C} / \mathrm{km}$, we estimate exhumation rates ranging from $0.5 \mathrm{~km} / \mathrm{Myr}$ to $1.6 \mathrm{~km} / \mathrm{Myr}$. We infer that this event marks the main exhumational period in the northern Pyrenees, when the northern massif was exhumed above the main frontal thrust (Figure 13d).

Our results are remarkably consistent with the timing of exhumation in the Western Pyrenees, about $200 \mathrm{~km}$ to the west, indicated by AFT and AHe ages ranging from $49 \pm 4$ to $35 \pm 3 \mathrm{Ma}$ in this region [Vacherat et al., 2014]. An exhumation rate of $0.2 \mathrm{~km} / \mathrm{Myr}$ from 44 to $35 \mathrm{Ma}$ deduced from AFT age elevation data in the Axial Zone (Maladeta massif of the Orri unit and Riberot pluton in the Nogueres unit) [Fitzgerald et al., 1999] reveals a regional exhumational event. Mountain building is further depicted by the growth of significant topography at 41-49 Ma as indicated by paleoelevation estimates of about $2000 \mathrm{~m}$ [Huyghe et al., 2012].

Plate kinematics and shortening data, however, reveal that the period 50-35 Ma was not associated with acceleration of convergence in the Pyrenees [e.g., Mouthereau et al., 2014]. The role of margin architecture is here proposed as the main element explaining enhanced mountain building processes at this time. In the western Pyrenees, Vacherat et al. [2014] suggested that this period marks the onset of collision with the more buoyant proximal margin. Such a mechanism was proposed to be the cause of the evolution from a submarine accretion prism to a subaerial mountain range in Taiwan [Mesalles et al., 2014]. In our study area, the analogy with the Taiwan case is supported by the timing of exhumation of the Camarade basin (circa $50 \mathrm{Ma}$ ), which marks the onset of northward emplacement of the hyperextended domain (hyperthinned domain and necking zone) of the European rifted margin onto the normally thinned crust of the Aquitaine foreland basin (proximal domain).

These results suggest that, as early proposed by Metcalf et al. [2009], the Central and Western Pyrenees began to develop as a prominent subaerial orogen mostly after $50 \mathrm{Ma}$, that is, about $30 \mathrm{Myr}$ after plate convergence initiated at $\sim 83 \mathrm{Ma}$. The initial, mostly submarine stage of accretion in the distal margin was not associated with a noticeable cooling in the studied massifs of Ariège (Figure 12). They underwent either slow cooling of $\sim 1.9^{\circ} \mathrm{C} /$ Myr after rifting at 130-110 Ma (southern flanks of 3S and Arize) or heating (northern flanks of 3S and Arize) as thermal relaxation is compensated by sediment burial. In any case, modeling shows that the massifs were at temperatures between $200^{\circ} \mathrm{C}$ and $300^{\circ} \mathrm{C}$ when shortening initiated at $83 \mathrm{Ma}$. For $30 \mathrm{Myr}$, temperatures were kept relatively high with a geothermal gradient as high as $80^{\circ} \mathrm{C} / \mathrm{km}$ according to Vacherat et al. [2014]. A part of the ductile deformation observed in the Mesozoic basins (Aulus / Saint-Girons) may be originated from this transitional period (Figure 13c). The highest temperature and penetrative ductile deformation are observed in these two basins that we suggest behave as a submarine accretionary wedge. These inferences are in agreement with thermal/shortening histories proposed by Mouthereau et al. [2014], who suggested that up to $70 \mathrm{~km}$ of shortening was accommodated in the distal domain during this period. 
Detrital fission track and (U-Th)/He ages collected in Cenozoic sediments of the northern foreland [Mouthereau et al., 2014] suggested that cooling started in the Late Cretaceous at 70-75 Ma, coherent with one of our $t-T$ scenario inferred from our forward modeling approach and in agreement with other thermochronologial studies in the SPZ [Beamud et al., 2011; Whitchurch et al., 2011; Filleaudeau et al., 2011]. Both studies rely on different approaches (bedrock and detrital thermochronology) and must be seen as complementary. Those results are reconciled if one assumes that shortening after $83 \mathrm{Ma}$ localized in the weakest, hottest, and thinnest part of the crust that is the Aulus/St Girons basins at a distance from the TroisSeigneurs and Arize granite massifs. Cooling below $110^{\circ} \mathrm{C}$ at $75-70 \mathrm{Ma}$ as argued by Mouthereau et al. [2014] to have occurred close to the NPF might indicate onset of underthrusting and/or faster thermal relaxation (caused by higher thinning) in Aulus/St Girons rifted basins.

\section{Conclusions}

In this study, we aimed to evaluate the role of rifted margin architecture in the tectonic and thermal evolution of the French central Pyrenees. In these objectives, we bring constraints on the tectonic and thermal evolution of the NPZ, with a focus on the Ariège area, using new low-temperature thermochronological data (AHe, AFT, ZHe, and ZFT) in the Arize and the Trois-Seigneurs massifs, including a new age elevation profile. We inverse modeled our data by considering each tectonic unit separately. This approach is proved to be particularly suitable to areas with complex tectonic framework evolving from rift-to-collision settings.

We show that the granitic massifs in the whole area recorded high temperatures $>200^{\circ} \mathrm{C}$, which are slightly lower or in agreement with RSCM temperatures and ductile stretching patterns observed in adjacent basins (Figure 5). After rifting at 130-115 Ma, the region was submitted to differential thermal history depending on the position relative to the extensional blocks of the Arize and 3S. Massifs did not clearly record cooling associated with the onset of convergence at $\sim 83 \mathrm{Ma}$. We suggest that compressive deformations were essentially accommodated in the hot Aulus basin during the initial period of submarine continental accretion between Iberia and Europe. During this period the European granitic massifs recorded temperatures between 300 and $200^{\circ} \mathrm{C}$, suggesting that the plutons might have also recorded deformation in the ductile regime. All the area was then rapidly cooled and exhumed between 50 and $35 \mathrm{Ma}$.

Comparison with recent results from the Mauléon basin [Vacherat et al., 2014] supports a tectonic model in which shortening and exhumational patterns were largely controlled by the preorogenic structure of the European rift domain. This study reveals how important the role of rift architecture of the margin is for advancing on our understanding of continental accretion and mountain building.

\section{Acknowledgments}

This study was supported by French National Research Agency (ANR Project PYRAMID, ANR-11-BS56-0031). We thank the staff of the different laboratories (CRPG, SARM, ISTerre, and IDES) for welcoming us and for their precious help during data acquisition. This is CRPG contribution number 2399. Supporting information related to this article are included as three tables and one figure. We are greately thankful to Taylor Schildgen and to the two anonymous reviewers for their very detailed reviews and for valuable comments that greatly helped to improve the quality of the manuscript.

\section{References}

Baby, P., P. Crouzet, M. Specht, and J. Déramond (1988), Rôle des paléostructures Albo-Cénomaniennes dans la géométrie des chevauchements frontaux nord-pyrénéens, C. R. Acad. Sci. Paris, 306, 307-313.

Beamud, E., J. A. Muñoz, P. Fitzgerald, S. Baldwin, M. Garcés, L. Cabrera, and J. Metcalf (2011), Magnetostratigraphy and detrital apatite fission track thermochronology in syntectonic conglomerates: Constraints on the exhumation of the south-central Pyrenees, Basin Res., 23, 309-331, doi:10.1111/j.1365-2117.2010.00492.x.

Beaumont, C., J. A. Muñoz, J. Hamilton, and P. Fullsack (2000), Factors controlling the Alpine evolution of the central Pyrenees inferred from a comparison of observations and geodynamical models, J. Geophys. Res., 105, 8121-8145, doi:10.1029/1999JB900390.

Bellahsen, N., F. Mouthereau, A. Boutoux, M. Bellanger, O. Lacombe, L. Jolivet, and Y. Rolland (2014), Collision kinematics in the western external Alps, Tectonics, 33, 1055-1088, doi:10.1002/2013TC003453.

Beltrando, M., G. Manatschal, G. Mohn, G. V. Dal Piaz, A. Vitale Brovarone, and E. Masini (2014), Recognizing remnants of magma-poor rifted margins in high-pressure orogenic belts: The Alpine case study, Earth Sci. Rev., 131, 88-115, doi:10.1016/j.earscirev.2014.01.001.

Bernet, M. (2009), A field-based estimate of the zircon fission-track closure temperature, Chem. Geol., 259, 181-189, doi:10.1016/ j.chemgeo.2008.10.043.

Bernet, M., and J. I. Garver (2005), Fission-track analysis of detrital zircon, Rev. Mineral. Geochem., 58, 205-238, doi:10.2138/rmg.2005.58.8.

Bickle, M. K., S. M. Wickham, H. J. Chapman, and H. P. J. Taylor (1988), A strontium, neodymium and oxygen isotope study of hydrothermal metamorphism and crustal anatexis in the Trois Seigneurs Massif, Pyrenees, France, Contrib. Mineral. Petrol., 100, 399-407, doi:10.1007/ BF00371371.

Bosch, G. V., A. Teixell, M. Jolivet, P. Labaume, D. Stockli, M. Doménech, and P. Monié (2016), Timing of Eocene-Miocene thrust activity in the western Axial Zone and Chaînons Béarnais (west-central Pyrenees) revealed by multi-method thermochronology, C. R. Geosci., doi:10.1016/j.crte.2016.01.001, in press.

Boulvais, P., P. de Parseval, A. D'Hulst, and P. Paris (2006), Carbonate alteration associated with talc-chlorite mineralization in the eastern Pyrenees, with emphasis on the St. Barthelemy Massif, Mineral. Petrol., 88, 499-526, doi:10.1007/s00710-006-0124-x.

Boulvais, P., G. Ruffet, J. Cornichet, and M. Mermet (2007), Cretaceous albitization and dequartzification of Hercynian peraluminous granite in the Salvezines Massif (French Pyrénées), Lithos, 93, 89-106, doi:10.1016/j.lithos.2006.05.001. 
Brandon, M. T., M. K. Rodent-Tice, and J. I. Garver (1998), Late Cenozoic exhumation of the Cascadia accretionary wedge in the Olympic Mountains, northwest Washington State, Geol. Soc. Am. Bull., 110, 985-1009, doi:10.1130/0016-7606.

Briqueu, L., and C. Innocent (1993), Datation U/Pb sur zircon et géochimie isotopique $\mathrm{Sr}$ et $\mathrm{Nd}$ du volcanisme Permien des Pyrénées occidentales (Ossau et Anayet), C. R. Acad. Sci., Ser. II, 316, 623-628.

Brunet, M. F. (1986), The influence of the evolution of the Pyrenees on adjacent basins, Tectonophysics, 129, 343-354, doi:10.1016/0040-1951 (86) $90260-X$.

Cassinis, G., P. Di Stefano, F. Massari, C. Neri, and C. Venturini (2000), Permian of South Europe and its interregional correlation, in Persian-Triassic Evolution of Tethys and Western Circum-Pacific, edited by H. Yin et al., pp. 37-70, Elsevier Sci.

Chelalou, R., T. Nalpas, R. Bousquet, M. Prevost, A. Lahfid, J. C. Ringenbach, and J. F. Ballard (2016), New sedimentological, structural and paleothermicity data on the Boucheville basin (eastern north Pyrenean zone, France), C. R. Geosci, doi:10.1016/j.crte.2015.11.008, in press.

Cherniak, D. J., and E. B. Watson (2000), Pb diffusion in zircon, Chem. Geol., 172, 5-24, doi:10.1016/S0009-2541(00)00233-3.

Chevrot, S., M. Sylvander, J. Diaz, M. Ruiz, A. Paul, and the PYROPE Working Group (2015), The Pyrenean architecture as revealed by teleseismic P-to-S converted waves recorded along two dense transects, Geophys. J. Int., 200, 1096-1107, doi:10.1093/gji/ggu400.

Choukroune, P. (1974), Structure et évolution tectonique de la Zone Nord Pyrénéenne. Analyse de la déformation dans une portion de chaîne á schistosité sub-verticale, PhD thesis, 306 pp., Univ. des Sciences et Techniques du Languedoc, Montpellier, France.

Choukroune, P. (1989), The ECORS Pyrenean deep seismic profile reflection data and the overall structure of an orogenic belt, Tectonics, 8 , 23-39, doi:10.1029/TC008i001p00023.

Clerc, C., and Y. Lagabrielle (2014), Thermal control on the modes of crustal thinning leading to mantle exhumation. Insights from Cretaceous Pyrenean hot paleomargins, Tectonics, 33, 1340-1359, doi:10.1002/2013TC003471.

Clerc, C., Y. Lagabrielle, M. Neumanier, J. Y. Reynaud, and M. De Saint Blanquat (2012), Exhumation of subcontinental mantlerocks: Evidence from ultramafic-bearing clastic deposits nearby the Lherz peridotite body, French Pyrenees, Bull. Soc. Geol. Fr., 183, 443-459, doi:10.2113/ gssgfbull.183.5.443.

Clerc, C., A. Lahfid, P. Monié, Y. Lagabrielle, C. Chopin, M. Poujol, P. Boulvais, J. C. Ringenbach, E. Masini, and M. De St Blanquat (2015), High-temperature metamorphism during extreme thinning of the continental crust: A reappraisal of the north Pyrenean passive paleomargin, Solid Earth, 6, 643-668, doi:10.5194/se-6-643-2015.

Corre, B., Y. Lagabrielle, P. Labaume, S. Fourcade, C. Clerc, and M. Ballèvre (2016), Deformation associated with mantle exhumation in a distal, hot passive margin environment: New constraints from the Saraillé Massif (Chaînons Béarnais, North-Pyrenean Zone), C. R. Geosci,, doi:10.1016/j.crte.2015.11.007.

Dauteuil, O., and L. E. Ricou (1989), Une circulation de fluides de haute température à l'origine du métamorphisme crétacé nord-Pyrénéen, Geodin. Acta, 3, 237-250, doi:10.1080/09853111.1989.11105190.

Debroas, E. J. (1990), Le flysch noir albo-cénomanien témoin de la structuration albienne à sénonienne de la Zone nord-pyrénéenne en Bigorre (Hautes-Pyrénées, France), Bull. Soc. Geol. Fr., 2, 273-285.

Denèle, Y., J. L. Paquette, P. Olivier, and P. Barbey (2011), Permian granites in the Pyrenees: The Aya pluton (Basque Country), Terra Nova, 24, 105-113, doi:10.1111/j.1365-3121.2011.01043.x.

Déramond, J., P. Baby, M. Specht, and G. Crouzet (1990), Géométrie des chevauchements dans la Zone nord-pyrénéenne ariégeoise précisée par le profil ECORS, Bull. Soc. Geol. Fr., 6, 287-294.

Deségaulx, P., F. Roure, and A. Villein (1990), Structural evolution of the Pyrenees: Tectonic inheritance and flexural behaviour in the continental crust, Tectonophysics, 182, 211-225, doi:10.1016/0040-1951(90)90164-4.

Dumitru, T. A. (1993), A new computer-automated microscope stage system for fission-track analysis, Nucl. Tracks Radiat. Meas., 21, 575-580, doi:10.1016/1359-0189(93)90198-I.

Fallourd, S., M. Poujol, P. Boulvais, J. L. Paquette, M. De Saint Blanquat, and P. Remy (2014), In situ LA-ICP-MS U-Pb titanite dating of $\mathrm{Na}-\mathrm{Ca}$ metasomatism in orogenic belts: The north Pyrenean example, Int. J. Earth Sci., 103, 667-682, doi:10.1007/s00531-0130978-1.

Filleaudeau, P. Y., F. Mouthereau, and R. Pik (2011), Thermo-tectonic evolution of the south-central Pyrenees from rifting to orogeny: Insights from detrital zircon U/Pb and (U-Th)/He thermochronometry, Basin Res., 23, 1-17, doi:10.1111/j.1365-2117.2011.00535.x.

Fillon, C., C. Gautheron, and P. Van Der Beek (2013), Oligocene-Miocene burial and exhumation of the southern Pyrenean foreland quantified by low-temperature thermochronology, J. Geol. Soc. London, 170, 67-77, doi:10.1144/jgs2012-051.

Fitzgerald, P. G., J. A. Muñoz, P. J. Coney, and S. L. Baldwin (1999), Asymmetric exhumation across the Pyrenean orogen: Implications for the tectonic evolution of a collisional orogeny, Earth Planet. Sci. Lett., 173, 157-170, doi:10.1016/S0012-821X(99)00225-3.

Flowers, R. M., R. A. Ketcham, D. L. Shuster, and K. A. Farley (2009), Apatite (U-Th)/He thermochronometry using a radiation damage accumulation and annealing model, Geochim. Cosmochim. Acta, 73, 2347-2365, doi:10.1016/j.gca.2009.01.015.

Fortané, A., G. Duée, Y. Lagabrielle, and A. Coutelle (1986), Lherzolites and the western "Chainons béarnais" (French Pyrenees): Structural and paleogeographical pattern, Tectonophysics, 129, 81-98, doi:10.1016/0040-1951(86)90247-7.

Galbraith, R. F., and G. M. Laslett (1993), Statistical models for mixed fission track ages, Nucl. Tracks Radiat. Meas., 21, 459-470, doi:10.1016/ 1359-0189(93)90185-C.

Gallagher, K. (2012), Transdimensional inverse thermal history modeling for quantitative thermochronology, J. Geophys. Res., 117, B02408, doi:10.1029/2011JB008825.

Gallagher, K., K. Charvin, S. Nielsen, M. Sambridge, and J. Stephenson (2009), Markov chain Monte Carlo (MCMC) sampling methods to determine optimal models, model resolution and model choice for Earth science problems, Mar. Pet. Geol., 26, 525-535, doi:10.1016/ j.marpetgeo.2009.01.003.

Garver, J. I., and P. J. J. Kamp (2002), Integration of zircon color and zircon fission-track zonation patterns in orogenic belts: Application to the Southern Alps, New Zealand, Tectonophysics, 349, 203-219, doi:10.1016/S0040-1951(02)00054-9.

Garver, J. I., P. W. Reiners, L. J. Walker, J. M. Ramage, and S. E. Perry (2005), Implications for timing of Andean uplift from thermal restting of radiation-damaged zircon in the Cordillera Huayhuash, Northern Peru, J. Geol., 113, 117-138, doi:10.1086/427664.

Gautheron, C., L. Tassan-Got, J. Barbarand, and M. Pagel (2009), Effect of alpha-damage annealing on apatite (U-Th)/He thermochronology, Chem. Geol., 266, 157-170, doi:10.1016/j.chemgeo.2009.06.001.

Gibson, M., H. D. Sinclair, G. J. Lynn, and F. M. Stuart (2007), Late- to post-orogenic exhumation of the Central Pyrenees revealed through combined thermochronological data and modeling, Basin Res., 19, 323-334, doi:10.1111/j.1365-2117.2007.00333.x.

Gleadow, A. J. W., A. J. Hurford, and R. D. Quaife (1976), Fission track dating of zircon: Improved etching techniques, Earth Planet. Sci. Lett., 33, 273-276, doi:10.1016/0012-821X(76)90235-1.

Gleizes, G., G. Crevon, and P. Barbey (2006), Structure, age and mode of emplacement of the Hercynian Bordères-Louron pluton (Central Pyrenees, France), Int. J. Earth Sci. (Geol. Rundsch.), 95, 1039-1052, doi:10.1007/s00531-006-0088-4. 
Godard, V., P. Pik, J. Lavé, R. Cattin, B. Tibari, J. De Sigoyer, M. Pubellier, and J. Zhu (2009), Late Cenozoic evolution of the central Longmen Shan, eastern Tibet: Insight from (U-Th)/He thermochronometry, Tectonics, 28, TC5009, doi:10.1029/2008TC002407.

Golberg, J. M., and A. F. Leyreloup (1990), High temperature-low pressure Cretaceous metamorphism related to crustal thinning (eastern north Pyrenean zone, France), Contrib. Mineral. Petrol., 104, 194-207, doi:10.1007/BF00306443.

Guenthner, W. R., P. W. Reiners, R. A. Ketcham, L. Nasdala, and G. Giester (2013), Helium diffusion in natural zircon: Radiation damage, anisotropy, and the interpretation of zircon (U-Th)/He thermochronology, Am. J. Sci, 313, 145-198, doi:10.2475/03.2013.01.

Guenthner, W. R., P. W. Reiners, and Y. Tian (2014), Interpreting date-eU correlations in zircon (U-Th)/He datasets: A case study from the Longmen Shan, China, Earth Planet. Sci. Lett., 403, 328-339, doi:10.1016/j.epsl.2014.06.050.

Hurford, A. J., and P. F. Green (1983), The zeta age calibration of fission-track dating, Isot. Geosci., 1, 285-317, doi:10.1016/50009-2541(83)80026-6.

Huyghe, D., F. Mouthereau, S. Castelltort, P. Y. Filleaudeau, and L. Emmanuel (2009), Paleogene propagation of the southern Pyrenean thrust wedge revealed by finite strain analysis in frontal thrust sheets: Implications for mountain building, Earth Planet. Sci. Lett., 288, 421-433, doi:10.1016/j.epsl.2009.10.002.

Huyghe, D., F. Mouthereau, and L. Emmanuel (2012), Oxygen isotopes of marine mollusk shells record Eocene elevation change in the Pyrenees, Earth Planet. Sci. Lett., 345-348, 131-141, doi:10.1016/j.epsl.2012.06.035.

Jammes, S., and R. S. Huismans (2012), Structural styles of mountain building: Controls of lithospheric rheologic stratification and extensional inheritance, J. Geophys. Res., 117, B10403, doi:10.1029/2012JB009376.

Jammes, S., G. Manatschal, L. L. Lavier, and E. Masini (2009), Tectonosedimentary evolution related to extreme crustal thinning ahead of a propagating ocean: Example of the western Pyrenees, Tectonics, 28, TC4012, doi:10.1029/2008TC002406.

Ketcham, R. A. (2005), Forward and inverse modeling of low-temperature thermochronometry data, Rev. Mineral. Geochem., 58, 275-314, doi:10.2138/rmg.2005.58.11.

Ketcham, R. A., A. Carter, R. A. Donelick, J. Barbarand, and A. J. Hurford (2007), Improved modeling of fission-track annealing in apatite, Am. Mineral., 92, 799-810, doi:10.2138/am.2007.2281.

Ketcham, R. A., C. Gautheron, and L. Tassan-Got (2011), Accounting for long alpha-particle stopping distances in (U-Th-Sm)/He geochronology: Refinement of the baseline case, Geochim. Cosmochim. Acta, 75, 7779-7791, doi:10.1016/j.gca.2011.10.011.

Lagabrielle, Y., and J. L. Bodinier (2008), Submarine reworking of exhumed subcontinental mantle rocks: Field evidence from the Lherz peridotites, French Pyrenees, Terra Nova, 20, 11-21, doi:10.1111/j.1365-3121.2007.00781.x

Lagabrielle, Y., P. Labaume, and M. De Saint Blanquat (2010), Mantle exhumation, crustal denudation, and gravity tectonics during Cretaceous rifting in the Pyrenean realm (SW Europe): Insights from the geological setting of the Iherzolite bodies, Tectonics, 29, TC4012, doi:10.1029/2009TC002588.

Lago, M., E. Arranz, A. Pocovi, C. Gale, and A. Gil-Imaz (2004), Permian magmatism and basin dynamics in the southern Pyrenees: A record of the transition from the late Variscan transtension to early Alpine extension, in Permo-Carboniferous Magmatism and Rifting in Europe, edited by M. Wilson et al., Geol. Soc. London Spec. Publ., 223, 439-464.

Lee, J. K. W., I. S. Williams, and D. J. Ellis (1997), Pb, U and Th diffusion in natural zircon, Nature, 390, 159-162, doi:10.1038/36554.

Le Pichon, X., J. Bonnin, and J. C. Sibuet (1970), La faille nord-pyrénéenne: Faille transformante liée à l'ouverture du Golfe de Gascogne, C. R. Acad. Sci. Paris, 271, 1941-1944.

Malusa, M. G., M. Danisik, and J. Kuhlemann (2015), Tracking the Adriatic-slab travel beneath the Tethyan margin of Corsica-Sardinia by low-temperature thermochronometry, Gondwana Res., doi:10.1016/j.gr.2014.12.011.

Manatschal, G. (2004), New models for evolution of magma-poor rifted margins based on a review of data and concepts from West Iberia and the Alps, Int. J. Earth Sci. (Geol. Rundsch.), 93, 432-466 doi:10.1007/s00531-004-0394-7.

Marzoli, A., P. R. Renne, E. M. Piccrillo, M. Ernesto, G. Bellieni, and A. De Min (1999), Extensive 200-million-year-old continental flood basalts of the Central Atlantic magmatic province, Science, 284, 616-618, doi:10.1126/science.284.5414.616.

Masini, E., G. Manatschal, G. Mohn, and P. Unternehr (2012), Anatomy and tectono-sedimentary evolution of a rift-related detachment system: The example of the Err detachment (central Alps, SE Switzerland), GSA Bull., 124, 1535-1551, doi:10.1130/B30557.1.

Masini, E., G. Manatschal, J. Tugend, G. Mohn, and J. M. Flament (2014), The tectono-sedimentary evolution of a hyper-extended rift basin: The example of the Arzacq-Mauléon rift system (western Pyrenees, SW France), Int. J. Earth Sci. (Geol. Rundsch.), 103, 1569-1596, doi:10.1007/s00531-014-1023-8.

Maurel, O., J. P. Respaut, P. Monié, N. Arnaud, and M. Brunel (2004), U-Pb emplacement and ${ }^{40} \mathrm{Ar} /{ }^{39} \mathrm{Ar}$ cooling ages of the Mont-Louis granite massif (Eastern Pyrenees, France), C. R. Geosci., 336, 1091-1098, doi:10.1016/j.crte.2004.04.005.

Maurel, O., P. Monié, R. Pik, N. Arnaud, M. Brunel, and M. Jolivet (2007), The Meso-Cenozoic thermo-tectonic evolution of the eastern Pyrenees: $\mathrm{An}^{40} \mathrm{Ar}{ }^{39} \mathrm{Ar}$ fission track and (U-Th)/He thermochronological study of the Canigou and Mont-Louis massifs, Int. J. Earth Sci., 97 , 565-584, doi:10.1007/s00531-007-0179-x.

McIntosh, K., H. Van Avendonk, L. Lavier, W. R. Lester, D. Eakin, F. Wu, C. S. Liu, and C. S. Lee (2013), Inversion of a hyper-extended rifted margin in the southern Central Range of Taiwan, Geology, 41, 871-874, doi:10.1130/G34402.1.

Mesalles, L., F. Mouthereau, M. Bernet, C. Chung-Pai, L. Andrew Tien-Shun, C. Fillon, and X. Sengelen (2014), From submarine continental accretion to arc-continent orogenic evolution: The thermal record in southern Taiwan, Geology, 42, 907-910, doi:10.1130/G35854.1.

Metcalf, J. R., P. G. Fitzgerald, S. L. Baldwin, and J. A. Muñoz (2009), Thermochronology of a convergent orogeny: Constraints on the timing of thrust faulting and subsequent exhumation of the Maladeta Pluton in the Central Pyrenean Axial Zone, Earth Planet. Sci. Lett., 287, 488-503, doi:10.1016/j.epsl.2009.08.036.

Michard-Vitrac, A., F. Albarède, C. Dupuis, and H. P. J. Taylor (1980), The genesis of Variscan (Hercynian) plutonic rocks: Inferences from $\mathrm{Sr}, \mathrm{Pb}$, and $\mathrm{O}$ studies on the Maladeta ignous complex, central Pyrenees (Spain), Contrib. Mineral. Petrol., 72, 57-72, doi:10.1007/BF00375568

Mohn, G., G. Manatschal, E. Masini, and O. Müntener (2011), Rift-related inheritance in orogens: A case study from the Austroalpine nappes in Central Alps (SE-Switzerland and N-Italy), Int. J. Earth Sci., 100, 937-961, doi:10.1007/s00531-010-0630-2.

Mohn, G., G. Manatschal, M. Beltrando, and I. Haupert (2014), The role of rift-inherited hyper-extension in Alpine-type orogens, Terra Nova, 26, 347-353, doi:10.1111/ter.12104

Montigny, R., B. Azambre, M. Rossy, and R. Thuizat (1986), K-Ar study of Cretaceaous magmatism and metamorphism in the Pyrenees: Age and length of rotation of the Iberian Peninsula, Tectonophysics, 129, 257-273, doi:10.1016/0040-1951(86)90255-6.

Morris, R. G., H. D. Sinclair, and A. J. Yelland (1998), Exhumation of the Pyrenean orogen: Implications for sediment discharge, Basin Res., 10, 69-85, doi:10.1040/j.1365-2117.1998.00053.x.

Mouthereau, F., A. B. Watts, and E. Burov (2013), Structure of orogenic belts controlled by lithosphere age, Nat. Geosci., 6, 785-789, doi:10.1038/ngeo1902. 
Mouthereau, F., P. Y. Filleaudeau, A. Vacherat, R. Pik, O. Lacombe, M. G. Fellin, S. Castelltort, F. Christophoul, and E. Masini (2014), Placing limits to shortening evolution in the Pyrenees: Role of margin architecture and implications for the Iberia/Europe convergence, Tectonics, 33, 2283-2314, doi:10.1002/2014TC003663.

Muñoz, J. A. (1992), Evolution of a continental collision belt: ECORS-Pyrenees crustal balanced cross-section, in Thrust Tectonics, edited by K. McClay, pp. 235-246, Chapman \& Hall, London.

Olivet, J. L. (1996), La cinématique de la plaque Ibérique, Bull. Cent. Rech. Explor.-Prod. Elf-Aquitaine, 20, 131-195.

Olivier, P., G. Gleizes, J. L. Paquette, and C. Munãz Sàez (2008), Structure and U-Pb dating of the Saint-Arnac pluton and the Assignan charnockite (Agly Massif): A cross-section from the upper to the middle crust of the Variscan eastern Pyrenees, J. Geol. Soc. London, 165, 141-152, doi:10.1144/0016-76492006-185.

Olsen, P. E. (1997), Stratigraphic record of the early Mesozoic breakup of Pangea in the Laurasia-Gondwana rift system, Annu. Rev. Earth Planet. Sci., 25, 337-401, doi:10.1146/annurev.earth.25.1.337.

Paquette, J. L., G. Gleizes, D. Leblanc, and J. L. Bouchez (1997), Le granite de Bassiès (Pyrénées): Un pluton syntectonique d'âge Westphalien. Géochronologie U-Pb sur zircons, C. R. Acad. Sci., 324, 145-158.

Pik, R., B. Marty, J. Carignan, and J. Lavé (2003), Stability of the Upper Nile drainage network (Ethiopia) deduced from (U-Th)/He thermochronometry: Implications for uplift and erosion of the Afar plume dome, Earth Planet. Sci. Lett., 215, 73-88, doi:10.1016/S0012-821X(03) 00457-6.

Poujol, M., P. Boulvais, and J. Kosler (2010), Regional-scale Cretaceous albitization in the Pyrenees: Evidence from in situ U-Th-Pb dating of monazite, titanite and zircon, J. Geol. Soc. London, 167, 751-767, doi:10.1144/0016-76492009-144.

Rahn, M. K., M. T. Brandon, G. E. Batt, and J. I. Garver (2004), A zero-damage model for fission-track annealing in zircon, Am. Mineral., 89, 473-484.

Reiners, P. W. (2005), Zircon (U-Th)/He thermochronometry, Rev. Mineral. Geochem., 58, 151-179, doi:10.2138/rmg.2005.58.6.

Reiners, P. W., and M. T. Brandon (2006), Using thermochronology to understand orogenic erosion, Annu. Rev. Earth Planet. Sci., 34, 419-466, doi:10.1146/annurev.earth.34.031405.125202.

Reiners, P. W., S. N. Thomson, D. McPhillips, R. A. Donelick, and J. J. Roering (2007), Wildfire thermochronology and the fate and transport of apatite in hillslope and fluvial environments, J. Geophys. Res., 112, F04001, doi:10.1029/2007JF000759.

Respaut, J. P., and J. R. Lancelot (1983), Datation de la mise en place synmétamorphe de la charnockite d'Ansignan (massif de l'Agly) par la méthode U/Pb sur zircons et monazites, Neues Jahrb. Mineral. Abh., 147, 21-34.

Roberts, M. P., C. Pin, J. D. Clemens, and J. L. Paquette (2000), Petrogenesis of mafic to felsic plutonic rock associations: The Calc-alkaline Quérigut Complex, French Pyrenees, J. Petrol., 41, 809-844, doi:10.1093/petrology/41.6.809.

Roest, W. R., and S. P. Srivastava (1991), Kinematics of the plate boundaries between Eurasia, Iberia, and Africa in the North Atlantic from the Late Cretaceous to the present, Geology, 19, 613-616, doi:10.1130/0091-7613.

Rosenbaum, G., G. S. Lister, and C. Duboz (2002), Relative motions of Africa, Iberia and Europe during Alpine orogeny, Tectonophysics, 359, 117-129, doi:10.1016/S0040-1951(02)00442-0.

Rossi, P., A. Cocherie, C. M. Fanning, and Y. Ternet (2003), Datation U-Pb sur zircons des dolérites tholéiitiques pyrénéennes (ophites) à la limite Trias-Jurassique et relations avec les tufs volcaniques dits « infra-liasiques » nord-pyrénéens, C. R. Geosci., 335, 1071-1080, doi:10.1016/j.crte.2003.09.011.

Shuster, D. L., R. M. Flowers, and K. A. Farley (2006), The influence of natural radiation damage on helium diffusion kinetics in apatite, Earth Planet. Sci. Lett., 249, 148-161, doi:10.1016/j.epsl.2006.07.028.

Sinclair, H. D., M. Gibson, M. Naylor, and R. G. Morris (2005), Asymmetric growth of the Pyrenees revealed through measurement and modeling of orogenic fluxes, Am. J. Sci., 305, 369-406, doi:10.2475/ajs.305.5.369.

Tagami, T., R. F. Galbraith, R. Yamada, and G. M. Laslett (1998), Revised annealing kinetics of fission tracks in zircon and geological implications, in Advances in Fission-Track Geochronology, edited by P. Van den Haute and F. De Corte, pp. 99-112, Kluwer Acad., Dordrecht, Netherlands.

Ternet, Y., C. Majesté-Menjoulas, J. Canérot, T. Baudin, A. Cocherie, C. Guerrot, and P. Rossi (2004), Notice explicative de la feuille Laruns-Somport, 1/50000, BRGM, $192 \mathrm{pp}$

Tibari, B., A. Vacherat, M. Stab, R. Pik, D. Yeghicheyan, and P. Hild (2016), An alternative protocol for single zircon analysis by ICP-MS, Geostand. Geol. Res., doi:10.1111/j.1751-908X.2016.00375.x, in press.

Tugend, J., G. Manatschal, N. J. Kuznir, E. Masini, G. Mohn, and I. Thinon (2014), Formation and deformation of hyperextended rift systems: Insights from rift domain mapping in the Bay of Biscay-Pyrenees, Tectonics, 33, 1239-1276, doi:10.1002/2014TC003529.

Tugend, J., G. Manatschal, and N. J. Kuznir (2015), Spatial and temporal evolution of hyperextended rift systems: Implication for the nature, kinematics, and timing of the Iberian-European plate boundary, Geology, 43, 15-18, doi:10.1130/G36072.1.

Vacherat, A. (2014), Inversion d'un domaine hyper-amincie: Context thermo-cinématique et interactions tectonique-érosion au Nord des Pyrénées, PhD thesis, 545 pp., Univ. Pierre et Marie Curie, Paris.

Vacherat, A., F. Mouthereau, R. Pik, M. Bernet, C. Gautheron, E. Masini, L. Le Pourhiet, B. Tibari, and A. Lahfid (2014), Thermal imprint of rift-related processes in orogens as recorded in the Pyrenees, Earth Planet. Sci. Lett., 408, 296-306, doi:10.1016/j.epsl.2014.10.014.

Vauchez, A., C. Clerc, L. Bestani, Y. Lagabrielle, A. Chauvet, A. Lahfid, and D. Mainprice (2013), Preorogenic exhumation of the North Pyrenean Agly massif (Eastern Pyrenees-France), Tectonics, 32, 95-106, doi:10.1002/tect.20015.

Vermeesch, P. (2009), RadialPlotter: A Java application for fission track, luminescence and other radial plots, Radiat. Meas., 44, 409-410, doi:10.1016/j.radmeas.2009.05.003.

Vermeesch, P. (2012), On the visualization of detrital age distributions, Chem. Geol., 312-313, 191-194, doi:10.1016/j.chemgeo.2012.04.021.

Vielzeuf, D., and J. Kornprobst (1984), Crustal splitting and the emplacement of Pyrenean Iherzolites and granulites, Earth Planet. Sci. Lett., 67, 87-96, doi:10.1016/0012-821X(94)90041-4.

Vissers, R. L. M. (1992), Variscan extension in the Pyrenees, Tectonics, 11, 1369-1384, doi:10.1029/92TC00823.

Whitchurch, A. L., A. Carter, H. D. Sinclair, R. A. Duller, A. C. Whittaker, and P. A. Allen (2011), Sediment routing system evolution within a diachronously uplifting orogen: Insights from detrital zircon thermochronological analyses from the south-central Pyrenees, Am. J. Sci., 311, 442-482, doi:10.2475/05.2011.03.

Wickham, S. M., and H. P. J. Taylor (1985), Stable isotopic evidence for large-scale seawater infiltration in a regional metamorphic terrane; the Trois-Seigneurs Massif, Pyrenees, France, Contrib. Mineral. Petrol., 91, 122-137, doi:10.1007/BF00377760.

Yamada, R., M. Murakami, and T. Tagami (2007), Statistical modeling of annealing kinetics of fission tracks in zircon; reassessment of laboratory experiments, Chem. Geol., 236, 75-91, doi:10.1016/j.chemgeo.2006.09.002.

Yelland, A. J. (1990), Fission track thermotectonics in the Pyrenean orogen, Nucl. Tracks Radiat. Meas., 17, 293-299, doi:10.1016/1359-0189 (90)90049-4.

Yelland, A. J. (1991), Thermo-tectonics of the Pyrenees and Provence from fission track studies, PhD thesis, Univ. of London. 